\title{
Eclogite facies relics in metabasites from the Sierra de Guadarrama (Spanish Central System): P-T estimations and implications for the Hercynian evolution
}

\author{
L. BARBERo ${ }^{1 * *}$ AND C. VILlaseCA ${ }^{2}$
}

${ }^{1}$ Departamento de Geología, Facultad C. C. del Mar, Universidad de Cádiz, 11510 Puerto Real, Cádiz, Spain

${ }^{2}$ Departamento de Petrología y Geoquímica, Facultad C. C. Geológicas, Universidad Complutense, 28040 Madrid, Spain

Relics of HP-MT eclogitic assemblages related to the first metamorphic stage of the Hercynian orogeny in the Sierra de Guadarrama (Spanish Central System. SCS) are preserved as boudins of pre-Ordovician metabasites enclosed by felsic gneisses. Textures indicate a multi-stage metamorphic history starting in the $M T$ eclogite facies (as deduced from the presence of mphacite and rutile included in garnet) and confining through medium to low pressure gramulite and retrograde amphibolite-greenschist facies. Thermobarometric calculations in the eclogitic $\mathrm{I}^{\mathrm{s}} \mathrm{Tagenesis} \mathrm{yield} \mathrm{pressures} \mathrm{of} \sim 14 \mathrm{kbar}$ for termperatures in the range $725-775^{\circ} \mathrm{C}$. Themobarometry for the subsequent granulieic stage indicates a simificane drop in pressure $(P<10 \mathrm{kbar})$ for similar temperatures of $\sim 750^{\circ} \mathrm{C}$. Metabasites vary from gabbro to lewcotonalites showing the typical Fe enrichment of the tholeiitic series. Chemical characteristics indicate a derivation from low-pressure crystallization of tholeitic melts more enriched than typical MORB compositions. Their original location far from continental margins as evidenced by the absence of ophiolitic material in the area and their association with platform sediments suggests that eclogitization was related to intracontinental crustal subduction and thickening. The $P-T$ conditions estimated in the metabasites for the first metamorphic stage are similar to ones deduced for the surounding metasediments and suggest that the Hercynian crust could have reached a thickness of $\sim 70-80 \mathrm{~km}$, which is more than the double the present thickness.

KeYwords: cclogitc assemblage, Spanish Central Systcm, Hercynitan evolution, MORB.

\section{Introduction}

The Sierra de Guadarrama is located in the axial zone of the Iberian branch of the Hercynian belt (Fig. 1) in the so-called Central Iberian Zone (San José et al. 1990). This sector represents a (ypicial intracontinental setting as seen from its location far from recognized ophiolitic complexes or supposed continental margins. The nearest ophio-

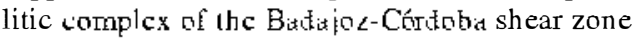
is located $>320 \mathrm{~km}$ to the southwest even after the shortening which occurred during the Hercynian orogeny. The melamorphic evolution related to

*E-mail: luis.barbero@uca.es the Hercynian orogeny is characterized by three stages of re-crystallization related to a single metamorphic cycle (Villaseca, 1983; Arenas et al., 1991). The initial metamorphism $\left(\mathbf{M}_{\mathbf{1}}\right)$ coincides with the first and with part of the second deformative events $\left(D_{1}\right.$ and $\left.D_{2}\right)$ and is charactiorifed hy a medium $P$ - $T$ reginc associated with crustal thickening and progressive burial. The most characteristic large-scale $\mathrm{D}_{1}$ compressional structure in the study area is a series of kmscale ductile shear zones of orthogneisses imbricated with thin sheets of metasediments (Fig. 1) (Maciay et al., 1991). In prcvious works, the precise metamorphic conditions of $M_{1}$ have not been established precisely, which was explained as a consequence of the overprinting by the second melanmophic stage $\left(\mathrm{M}_{2}\right)$. Villaseca 

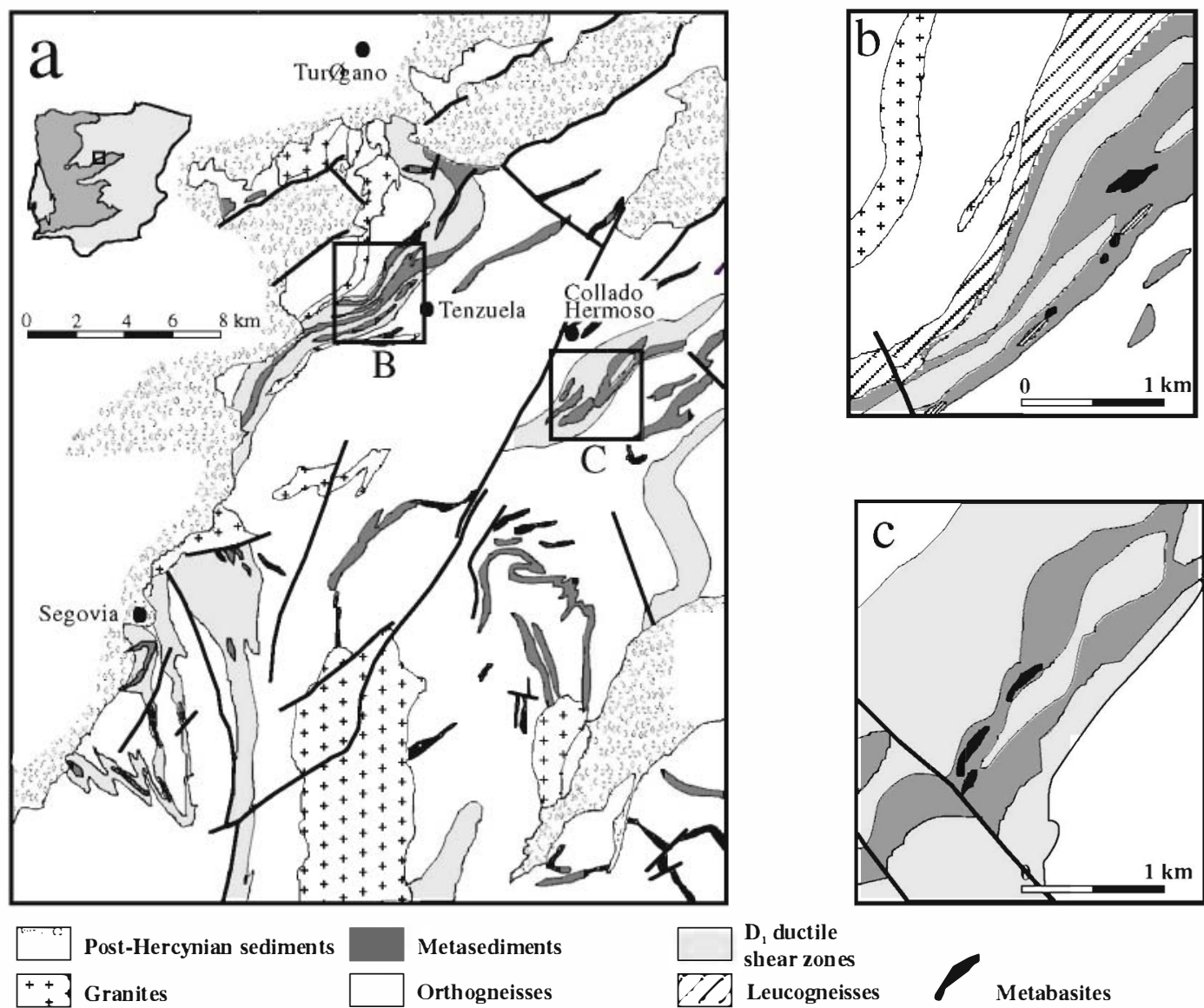

FIG. 1. (a) Geological map of a sector of the Central Spain Region (Hercynian orogen) and its location in the Iberian Hercynian Belt (grey area). The two insets are the main regions where the studied metabasites crop out; $(b)$ the Tenzuela sector; and (c) the Collado Hermoso sector.

(1983) describes these metabasic rocks as having a relict eclogitic assemblage, citing the presence of Na-rich pyroxenes included in garnets. The maximum pressure attained was estimated to be 7-11 kbar. In a more recent work on these metabasites, Villaseca and Barbero (1994) made a brief revision of the $P T$ conditions of the first Hercynian metamorphic episode concluding that the minimum pressure achieved was $\sim 9 \mathrm{kbar}$, probably reaching up to $12-15$ kbar for temperatures in the range $650-750^{\circ} \mathrm{C}$. The second metamorphic stage $\left(\mathrm{M}_{2}\right.$, paroxysmal metamorphism) coincides with the final development of the second deformation episode $\left(D_{2}\right)$, which is essentially an extensional event which overprints and transposes $\mathrm{D}_{1}$ structures generating some $\mathrm{km}$ - scale ductile extensional shear zones such as the Berzosa-Riazazone to the east of the studied area (Escuder Viruete et al., 1998). During $\mathrm{M}_{2}$, this orogenic segment reached the highest temperature (715 C, 4-5 kbar, Villaseca, 1983; Arenas et al., 1991) and a decompressional evolution occurred. Mineral parageneses of the $\mathrm{M}_{2}$ stage are generally well preserved and define a granulite facies metamorphic zone with orthoclase, cordierite and sillimanite. Migmatization occurred mainly in the quartzo-feldspathic meta-igneous and metapelitic protoliths associated with these metabasites. In nearby granulitic terranes such as the Anatectic Complex of Toledo located 100 $\mathrm{km}$ to the south of the study area, the metamorphic climax reached $800 \pm 50^{\circ} \mathrm{C}$ and 
$5 \pm 1 \mathrm{kbar}$ (Barbero, 1995). Finally. a third me atmor Thic stage $\left(\mathrm{V}_{3}\right)$. prodiced a retrogression of the previous parageneses during the last decompressional stage. The $\mathbf{M}_{3}$ mineral assemblages reflect greenschist facies conditions of $\sim 450^{\circ} \mathrm{C}$ and $2 \mathrm{kbar}$ (Villaseca, 1983; Arenas et al., 1991).

In the present work, new mineral chemical data on the relict eclogitic paragenesis of the $M_{1}$

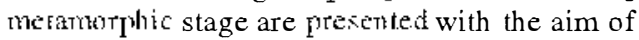
determining the $P-T$ eclogitic conditions attained during the Hercynian metamorphic evolution of this area. Moreover, new whole-rock chemical data on these metabasites have been obtained which, together with previous data (Villaseca, 1983; Villaseca et al., 1993), may place comstraims on the significatice of the basic magmatism during pre-Ordovician times.

\section{Geological setting}

The Sierra de Guadarrama is conposed nuinly of metamorphic rocks, both metasedimentary and meta-igneous types, into which voluminous peraluminous late Hercymitur granitcs intruded tig. $1 j$.

The metasedimentary sequences, of uncertain age, crop out under the Sardic uncorfomity (Lower Ordovician-Middle Devonian). Significant palaeontological remains are absent, which together with the fact that these sedimentary sequences are intruded by many pre-Ordoviciets rncti-igncous rocks, make stratigraphic correlation very difficult. A succession of schists and paragneisses, with quartzites, and discontinuous laycrs of marbles, amphibolites and calc-silicate rocks form the majority of the series This series of Proterozoic age is assigned to the so-called Complejo Esquisto Grauváquico of the Central Iberian Zone (San José et al., 1990). The presence of abundant layers of metapelites with a homfelslike appearance surrounded by meta-igneous types is characteristic. These melit-igncous types comprise different augen, porphyritic, and leucocratic varieties intruded into the pre-Ordovician sedimentary sequence, described previously. Gonchronological kita obtained from orthoyncissic rocks suggest an early Ordovician age (470-500 Ma Rb-Sr whole rock, Vialette et al, 1987; 487 Ma, U-Pb zircon Valverdc-Vayucro et al., 1995). These Lower Ordovician orthonteisses are mainly acidic varying from gramodiositic to leucograntic types. Almost all of them have a peralumirous composition with a tendency to be more peraluminous towards more basic compositions, thus having S-type characteristics.

Two types of basic meta-igneous rocks appear in the area, both of them restricted exclusively to the central domain of the Sierra de Guadarrama. The metabasites with eclogitic relics have never been found interlayered within the abundant lower Ordovician orthogneisses (Fig. 1). These older metabasites crop out as discontinuous bands, boudins or lenses within the Precambrian metasediments against which they present sharp contacts. They were intensively recrystallized during the Hercynian orogeny, heitig transformed into anplibolitic gueisses and garnetiferous mela-amphibolites. Based on several characteristics (discussed below) they are interpreted as heing derived from tholeiitic sills of undetermined Precambrian age, at least previous to the orthogneisses of Lower Ordovician age. A significtnl variation in composition from gabbros towards leucotonalites is observed (Villaseca, 1983). It is only in these metabasites in which the residual eclogitic mineral assemblages studied in the present work appear.

A second group of metabasites, conposed of coronitic metagabbros and metadiorites, intruded into all of the previous stratigraphic series (not alone into the melisckimentary Proterozoic sequences, but also into the Lower Ordovician felsic orthogneisses). Because of their tendency to appear in shear zones related to the compressional deformation stage, they have been intcrprcled to be early Hercynian in age, associated with the Hercynian crustal thickening (Villaseca, 1985) These coronitic metagabbros, in contrast to the metabasites described previously, are not as intensely re-crystallized, and some of them even preserve clear igneous textures in the internal zones of the massifs. No evidence of important highpressure re-crystallization has been found in this metabasite and garnet-bearing varieties are very rare. They are interpreted as sylt-orogenic continental tholeiitic sills because of their low alkalies and high $\mathrm{Ti}$ and Fe contents (Villaseca, 1985)

\section{Analytical methods}

For this stody, $\sim 50$ samples of amphibolitic metabasites from the region of Turégano (near Scgovia, Fig. 1) were investigatcd petrographicully The mineral issonzlages are summarized in Table 1. Electron microprobe analyses were performed on seven polished sections using three different microprobes: a JEOL 
TABLE 1. Relation of the blastesis of the different mineral phases with respect to the three metamorphic stages of the Spanish Central System.

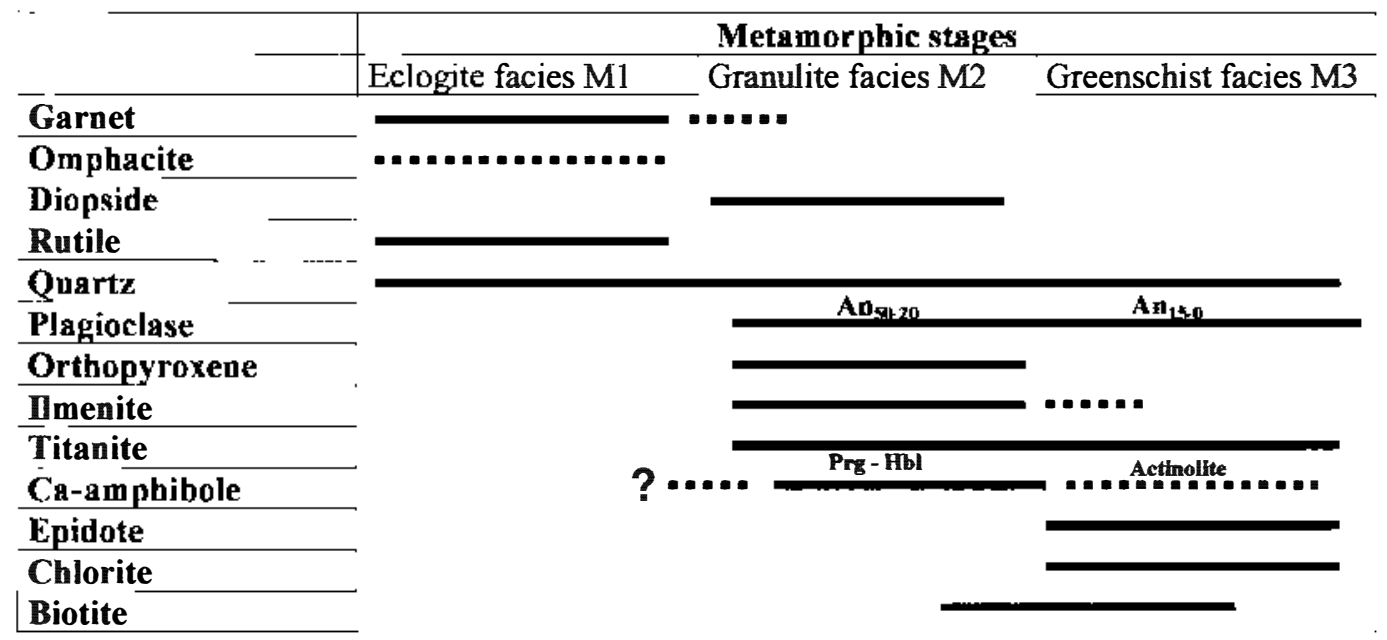

SUPERPROBE JXA 8900-M at Complutense University of Madrid; a JEOL SUPERPROBE 733 at St. Andrews University (UK); and a CAMECA SX-50 at Oviedo University (Spain). In all cases, the operating conditions were $15 \mathrm{kV}$, $20 \mathrm{nA}$, and a beam diameter of $2-5 \mu \mathrm{m}$, and ZAF correction procedure was used. Analyses performed on the same mineral grain in the different microprobes gave similar results.

Whole-rock major elements were determined by ICP-AES and trace elements by ICP-MS at CNRS (Nancy, France) following the method of Govindaraju and Mevelle (1987). Three wholerock chemical analyses have been taken from Villaseca (1983) (Table 5). The mineral abbreviations follow those used by Kretz (1983).

\section{Sample description}

Metabasic rocks containing high-pressure relics appear in the Turégano region (Fig. 1) as boudins of variable size included in the metasediments. The largest outcrop occurs near Tenzuela (Fig. $1 b$ ) where a varied and complex massif of metabasites of $\sim 2000 \mathrm{~m}^{2}$, showing concordant sharp contacts with the surrounding metapelites and marbles, is exposed. In this massif, several types can be distinguished: granoblastic leucoamphibolites with varied grain size; foliated melaamphibolites interlayered with the former leucocratic types; and medium- to fine-grained garnet- bearing amphibolites with a massive structure and an eclogite-like appearance, generally found as rounded masses included within the former rock types. Some pegmatitic varieties with conspicuous amphibole, plagioclase and quartz crystals appear. A second important group of small outcrops of metabasites are located to the south of the Collado Hermoso village (Fig. 1c).

Different mineral assemblages, which are the result of the successive metamorphic recrystallization stages, can be distinguished. In Table 1 the relation between the blastesis of the different mineral phases and the three metamorphic stages of the area are summarized.

\section{Eclogitic relict paragenesis}

This comprises minerals grown during the $M_{1}$ stage including garnet, Na-rich-clinopyroxene, amphibole (?), ilmenite (?), rutile and apatite. Most of these minerals are found as inclusions in garnet domains.

\section{Granulitic paragenesis}

This was imposed on the previous assemblage; plagioclase, clinopyroxene (low-Na), orthopyroxene, amphibole and some biotite and $\mathrm{K}$-feldspar in the more felsic varieties appear. These phases are related to the second metamorphic re-crystallization. 
Finally, the retrogression of the previous assemhlages during the $\mathbf{M}_{3}$ stage produces minerals such as chlorite, actinolite, quartz and epidote (Table 1).

Garnet appears in proportions varying from accessory amounts up to $20 \%$ in certain samples (Fig. 2). It is more or less equidimensionil and varies in form from euhedral to anhedral(atoll or ameboid forms); gritin sizes are up to $2 \mathrm{~mm}$ and of sieved textural appearance, as a consequence of the abundant clinopyroxene, quartz, plagioclase, amphibole, orthopyroxene, biotite, apatite, rutile and ilmenite inclusions, usually observed (Fig. 2). In these complex garnet domains, some of these minerals (clinopyroxene, quartz, rutile) should be interpreted as primary inclusions entraped Auring the garnet growth. Other inclusions (plagioclase, amphibole, biotite, orthopyroxene, ilmenite) clearly post-date garnet growth and can be interpreted as secondary inclusions or reaction products inside gamet. The presence of plagioclase coronas around clinopyroxene inclusions (Fig. 2d) suggests that the plagioclasc enclosed in garnet could have re-cyystillized furing the second metamephic stage, as could also be the case for the orthopyroxene, amphibole, biotite, ilmenite and quartz. The presence of a continuous plagioclase corona around garnet, sometimes with symplectitic intergrowths with amphibole and/or ilmenite in the external part of the corona (Fig. 2c), is clcarly related to the $\mathrm{M}_{2}$ Iccrystallization. In the most retrograde eclogites, where garnet and clinopyroxene have been almost completely destroyed, granoblastic plagioclase aggregates develop an exsolution-like texture as seen in the alignment of tiny needle-like inclusions of apatite and diopsidic clinopyroxene.

It is possible to find omphacitic clinopyroxene as relics of the $M_{1}$ paragenesis (as discussed in the mineral chemistry section), thus reflecting highpressure conditions. Clinopyroxene is found either as small inclusions in the garnet or as euhedral crystals in the matrix, in this case defiristg, together with the amphibole. plagioclase, orthopyroxene and quartz, the granonematoblastic texture of the rock. A thin plagioclase film usually surrounds clinopyroxene inclusions, which isolates them from the garnet (Fig. 2d). Orthopyroxere is much less abundant and appears either as small crystals appirenty included in the garnet or more commonly in the matrix. Orthopyroxene is restricted to certain sitnples from the Tenzuela massif (Fig. 1)
Amphibole is the most abundant ferromagnesian phase in these metabasites. It appears as subhedral granoblastic crystals but also as a continuous rim around ilmenite. It clearly grew later than the garnet, clinopyroxene and some of the $\mathrm{I}^{\mathrm{l}}$ aginclase. Sometimes amphibole appears to be symplectiticallyintergrown with plagincliase as an incomplete corona around garnet. It also appears as secondary inclusions within garnet, in this case robialy representing retrograded transformation of previous clinopyroxene inclusions. In the amphibole-rich varieties it appears as large nematoblastic crystals poikilitically enclosing residual garnet and usually developing a thin plagioclase film between both minerals.

Ilmenite is abundant in several types as elmgated crystals in the nematoblastic matrix of the rock Rutile is only found as inclusions in garnet. Titanite can frequently be found associated with ilmenite. Quartz is another accessory phase in these eclogitic metagabbros. Occasionally clinopyroxene plus plágioclase surround some corroded quartz aggregates.

\section{Mineral chemistry}

\section{Garnet}

The garnet composition in the metabasites is in the range of almandine (58-69 mol\%), grossular (24-30 mol. \% and pyrope (5-14 mol\%) with subordinate spessartine ( $<5.5 \mathrm{~mol}, \mathrm{j} / \mathrm{s})$ and uvarovite (<0.7 mol\%; (Table 2). Only in one samplc from the Collado Hermoso sector (sample 82245), is garnet slightly richer in grossular (30.0 to $33.6 \mathrm{~mol} \%$ ) and pyrope (12.0 to $14.0 \mathrm{~mol} . \%$ ) components (Fig. 3a) reflecting their relatively higher bulk-rock Ca composition. Garnets plot in the field of group $\mathrm{C}$ eclogites as defined by Coleman et al. (1965) (Fig. 3a). The majority of the metabasites contain unzoned garnets (Fig. $3 b$; or garnets in which zoning is not well defined. Nevertheless, when present, zoning is characterized by an increase in $\mathrm{Fe}$ and a decrease in $\mathrm{Ca}$ from core to rim (samples 82244 and 96897 , fig. $3 r, d$. Such zoning may have been caused by a pressure decrease (Raheim and Green, 1975) and is in agreement with the presence of retrograde plagioclase coronas around garnet.

\section{Clinopyroxene}

The lie $\mathrm{e}^{31}$ contents in clinopyroxeneare estimated, based on charge balance considerations, as the sum of cations is very close to 4 in all cases. As 

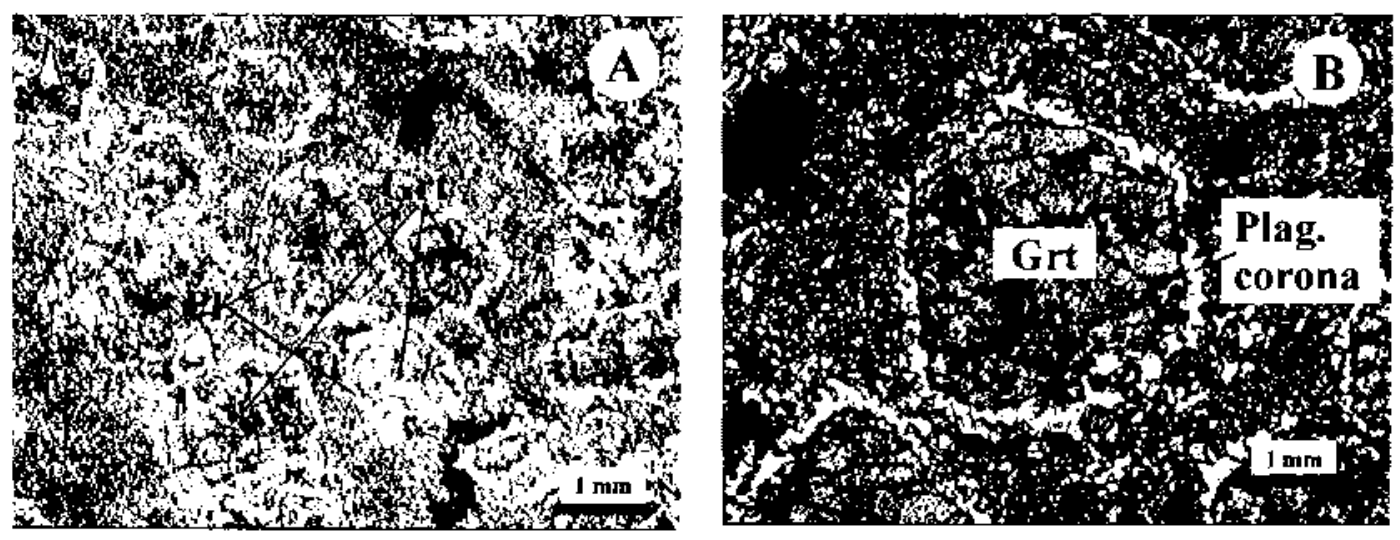

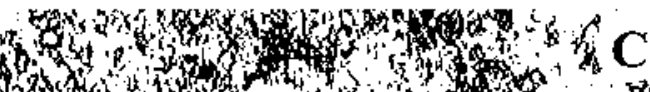

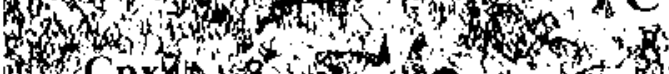

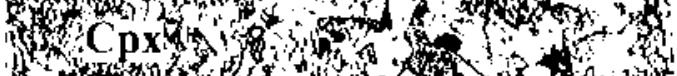
H 27

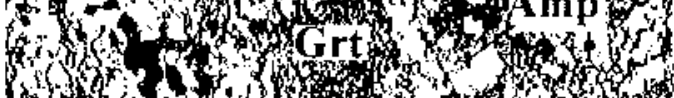

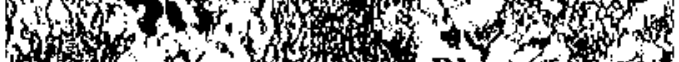

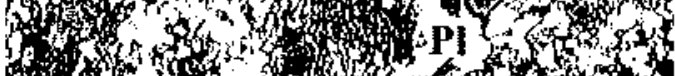

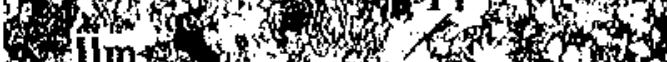

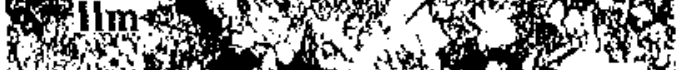
Swo

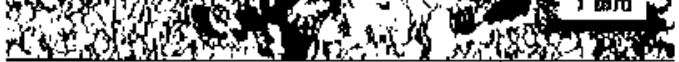
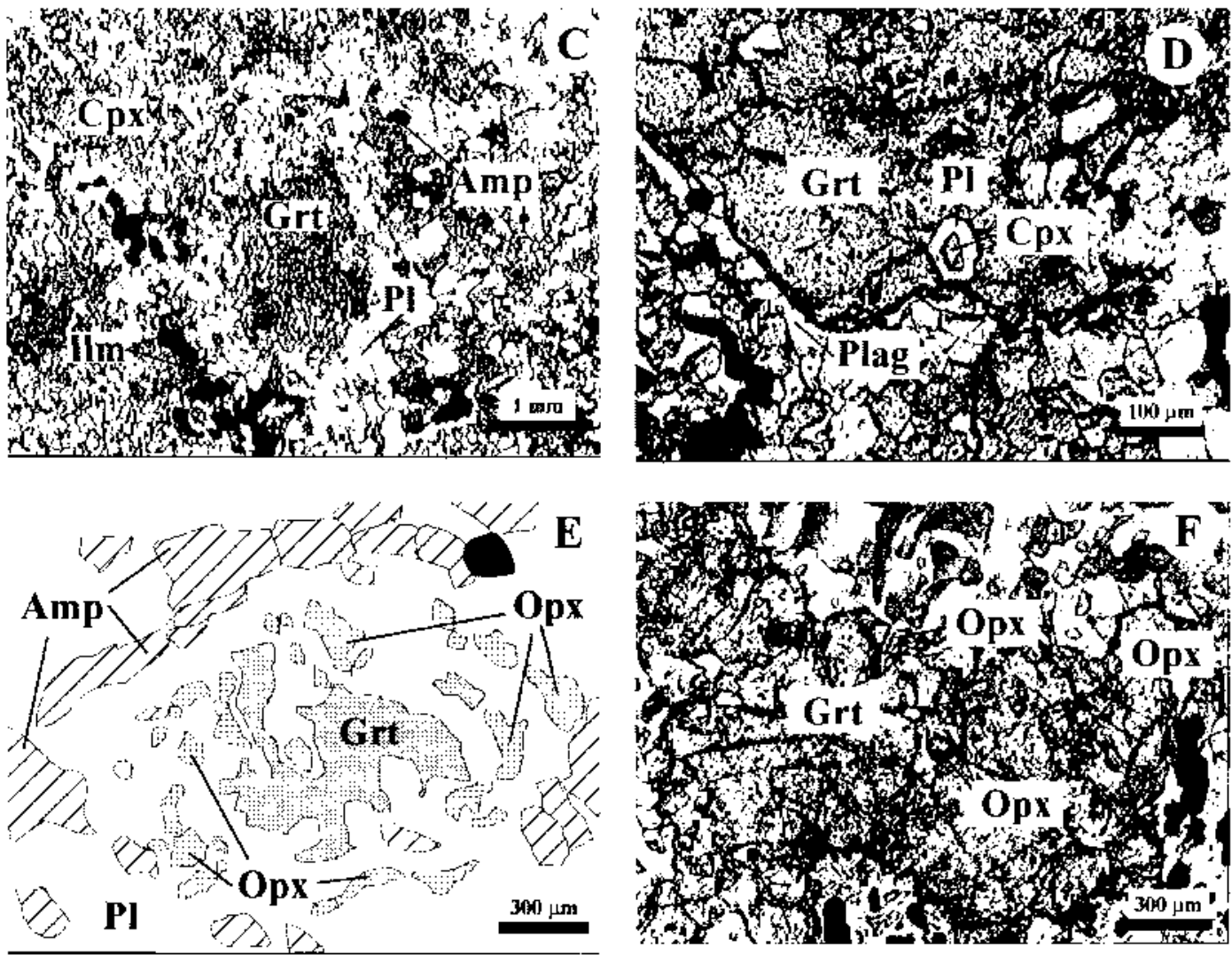

FIG. 2. Microtextural aspects of different metabasites from the studied area (a) General aspect of a retro-eclogite with plagioclase coronas around garnet and abundant ilmenite crystals; the matrix is composed mainly of granoblastic amphibole and plagioclase (sample 82244). (b) Detail of a plagioclase corona around a euhedral garnet (sample 71303). (c) Metabasite in a more retrograde stage showing a sieved-textured garnet and a coarse-grained granoblastic matrix composed of plagioclase, clinopyroxene, amphibole (also surrounding ilmenite) and ilmenite (sample 96894). (d) Detail of an omphacitic clinopyroxene included in garnet with a typical plagioclase corona between both minerals (sample 71300). (e) Petrographic scheme drawn from a microphotograph of sample 96894 showing the textural relations of the orthopyroxene $(\mathrm{Opx})$, plagioclase $(\mathrm{Pl})$, and amphibole (Amp) around a corroded garnet crystal. (f) Orthopyroxene inclusions in garnet from sample 96895. 
TABLE 2. Selected anlilyses of garnet of tholeiitic metabasites from the Sierra de Guadarrama.

\begin{tabular}{|c|c|c|c|c|c|c|c|c|c|c|}
\hline Siample & 71300 & 71300 & 71300 & 71300 & 96895 & 96895 & 82244 & 82244 & 82244 & 82244 \\
\hline Analysis & $103 \mathrm{rim}$ & 104 & 108 & 109 & 71 core & $74 \mathrm{rim}$ & $69 \mathrm{rim}$ & 70 & 72 & 73 core \\
\hline $\mathrm{SiO}_{2}$ & 39.02 & 38.09 & 38.41 & 38.81 & 38.42 & 38.15 & 37.02 & 37.28 & 37.39 & 37.68 \\
\hline $\mathrm{TiO}_{2}$ & 0.16 & 0.06 & 0.15 & 0.22 & 0.24 & 0.20 & 0.16 & 0.07 & 0.29 & 0.17 \\
\hline $\mathrm{Al}_{2} \mathrm{O}_{3}$ & 20.94 & 20.89 & 20.82 & 21.07 & 20.88 & 20.84 & 20.69 & 21.05 & 20.89 & 21.15 \\
\hline $\mathrm{FeO}$ & 29.88 & 30.45 & 29.18 & 28.39 & 28.21 & 29.58 & 28.27 & 28.49 & 28.74 & 28.14 \\
\hline $\mathrm{MnO}$ & 1.41 & 0.94 & 1.24 & 1.38 & 2.45 & 0.84 & 0.33 & 0.45 & 0.43 & 0.79 \\
\hline $\mathrm{MgO}$ & 1.76 & 1.85 & 2.41 & 2.43 & 1.53 & 1.86 & 2.87 & 2.72 & 2.71 & 2.62 \\
\hline $\mathrm{CaO}$ & 9.64 & 8.56 & 9.17 & 9.43 & 9.94 & 9.52 & 9.77 & 9.47 & 9.47 & 9.76 \\
\hline $\mathrm{Na}_{2} \mathrm{O}$ & 0.00 & 0.00 & 0.10 & 0.00 & 0.00 & 0.00 & 0.00 & 0.00 & 0.00 & 0.00 \\
\hline Total & 102.82 & 100.83 & 101.40 & 101.74 & 101.66 & 100.98 & 99.14 & 99.53 & 99.93 & 100.31 \\
\hline \multicolumn{11}{|c|}{ Structural formula $\mathrm{O}=12$} \\
\hline $\mathrm{Si}$ & 3.00 & 3.00 & 3.00 & 3.00 & 3.00 & 3.00 & 2.97 & 2.98 & 2.98 & 2.99 \\
\hline $\mathrm{Al}^{\mathrm{IV}}$ & 0.00 & 0.00 & 0.00 & 0.00 & 0.00 & 0.00 & 0.03 & 0.02 & 0.02 & 0.01 \\
\hline $\mathrm{AI}^{\mathrm{VI}}$ & 1.92 & 1.95 & 1.93 & 1.94 & 1.94 & 1.95 & 1.93 & 1.96 & 1.95 & 1.97 \\
\hline $\mathrm{Ti}^{\mathrm{VI}}$ & 0.01 & 0.00 & 0.01 & 0.01 & 0.01 & 0.01 & 0.01 & 0.00 & 0.02 & 0.01 \\
\hline $\mathrm{Mg}$ & 0.20 & 0.22 & 0.28 & 0.28 & 0.18 & 0.22 & 0.34 & 0.32 & 0.32 & 0.31 \\
\hline $\mathrm{Fe}^{2+}$ & 1.94 & 2.02 & 1.92 & 1.86 & 1.86 & 1.96 & 1. 90 & 1.90 & 1.92 & 1.87 \\
\hline $\mathrm{Mn}$ & 0.09 & 0.06 & 0.08 & 0.09 & 0.16 & 0.06 & 0.02 & 0.03 & 0.03 & 0.05 \\
\hline $\mathrm{Ca}$ & 0.80 & 0.73 & 0.77 & 0.79 & 0.84 & 0.81 & 0.84 & 0.81 & 0.81 & 0.83 \\
\hline \multicolumn{11}{|c|}{ End-members } \\
\hline Prp & 6.69 & 7.23 & 9.25 & 9.36 & 5.92 & 7.20 & 11.06 & 10.55 & 10.47 & 10.12 \\
\hline Alm & 63.85 & 66.68 & 62.76 & 61.45 & 61.12 & 64.40 & 61.14 & 62.03 & 62.29 & 61.02 \\
\hline Sps & 3.06 & 2.07 & 2.71 & 3.03 & 5.37 & 1.84 & 0.72 & 0.99 & 0.94 & 1.74 \\
\hline Gis & 26.40 & 24.01 & 25.27 & 26.15 & 27.58 & 26.56 & 26.97 & 26.42 & 26.27 & 27.12 \\
\hline
\end{tabular}

was the case for the garnets, clinopyroxene varies in composition depending on the whole rock chemistry, the metabasites $82244-5$ having the more diopsidic composition $\left(X_{\mathrm{Mq}_{\mathrm{q}}}=0.68-0.70\right.$ ) and the rest of the gabbroic types having $X_{\mathrm{Mg}}$ from 0.41 to 0.64 (Fig. 4) In samples 71300 and 96896 (Table 3), the clinopyroxenes included in garnet contain greater $\mathrm{Na}$ and $\mathrm{Al}$ contents than those in the matrix and also than those in the rest of the sample. The jadeite component in these inclusions varies from 1.0 to $20.5 \mathrm{~mol} \%$, some of the clinopyroxenes thus plotting in the omphacite field in Fig. 4. Omphacite relics are restricted to primary inclusions in garnet. They are absent from the gramnblastic matrix. Climopyroxeme included in garnet in sample 96895 has lower $\mathrm{Na}$ contents and $\mathrm{Mg} /(\mathrm{Fe}+\mathrm{Mg})$ ratios than that in the matrix (Fig. 4). Similar relict paragencses have been found in the matrix of cclogites from the Czech Republic (Medaris et al., 1995) where they have been interpreted as representing retrograded cclogicic stages.

\section{Orthopyroxene}

Orthopyroxene has been found only in some samples of the Tenzuela massif. Orthopyroxenes have compositions of $\sim X_{\mathrm{Mg}_{\mathrm{g}}}=0.29-0.38$ in sample 96896 and $X_{\mathrm{Mg}_{\mathrm{g}}}=0.37-0.43$ in sample 96895 , their chemical composition being controlled by the whole-rock chemistry. Although they appear as inclusions in the gamet they are more abundant in the matrix. Sometimes orthopyroxene appears to be associated with plagioclase and amphibole around garnet, suggesting its involvement in garnet breakdown reactions as discussed below (Fig. 2e). No important chemical differences have been found between the different textural types, with the exception of slightly higher $\mathrm{Al}_{2} \mathrm{O}_{3}$ contents in orthopyroxene included in garnet (up to $1.1 \mathrm{wt} . \%$, Table 3 )

\section{Amphibole}

Structural formulae have been calculated to 13 cations excluding $\mathrm{Ca}, \mathrm{Na}$ and $\mathrm{K}$; $\mathrm{Fe}^{3+}$ has been 


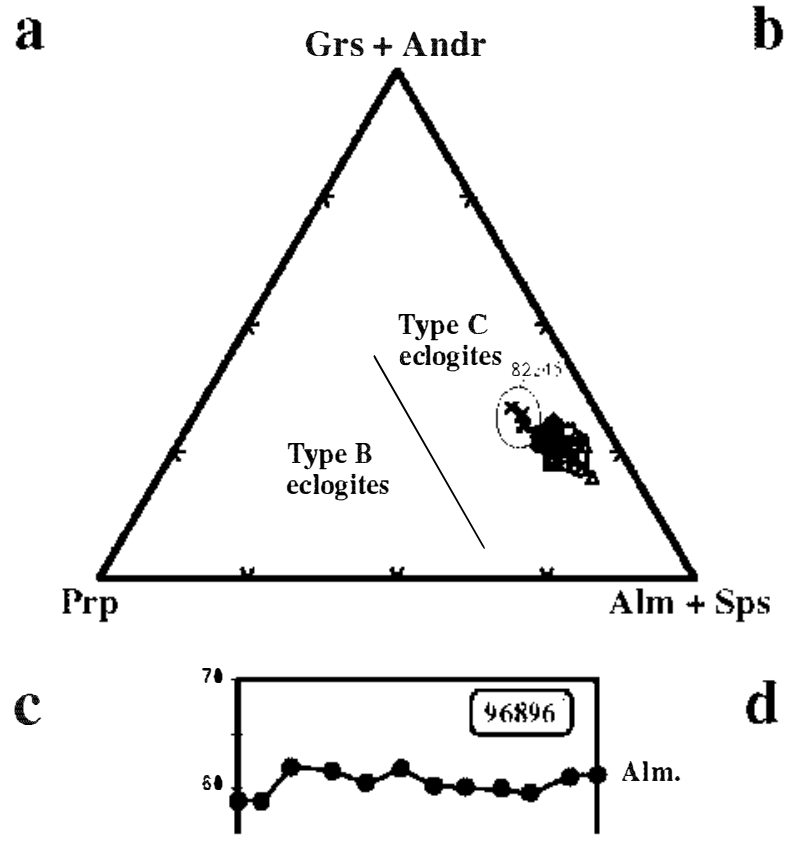

b
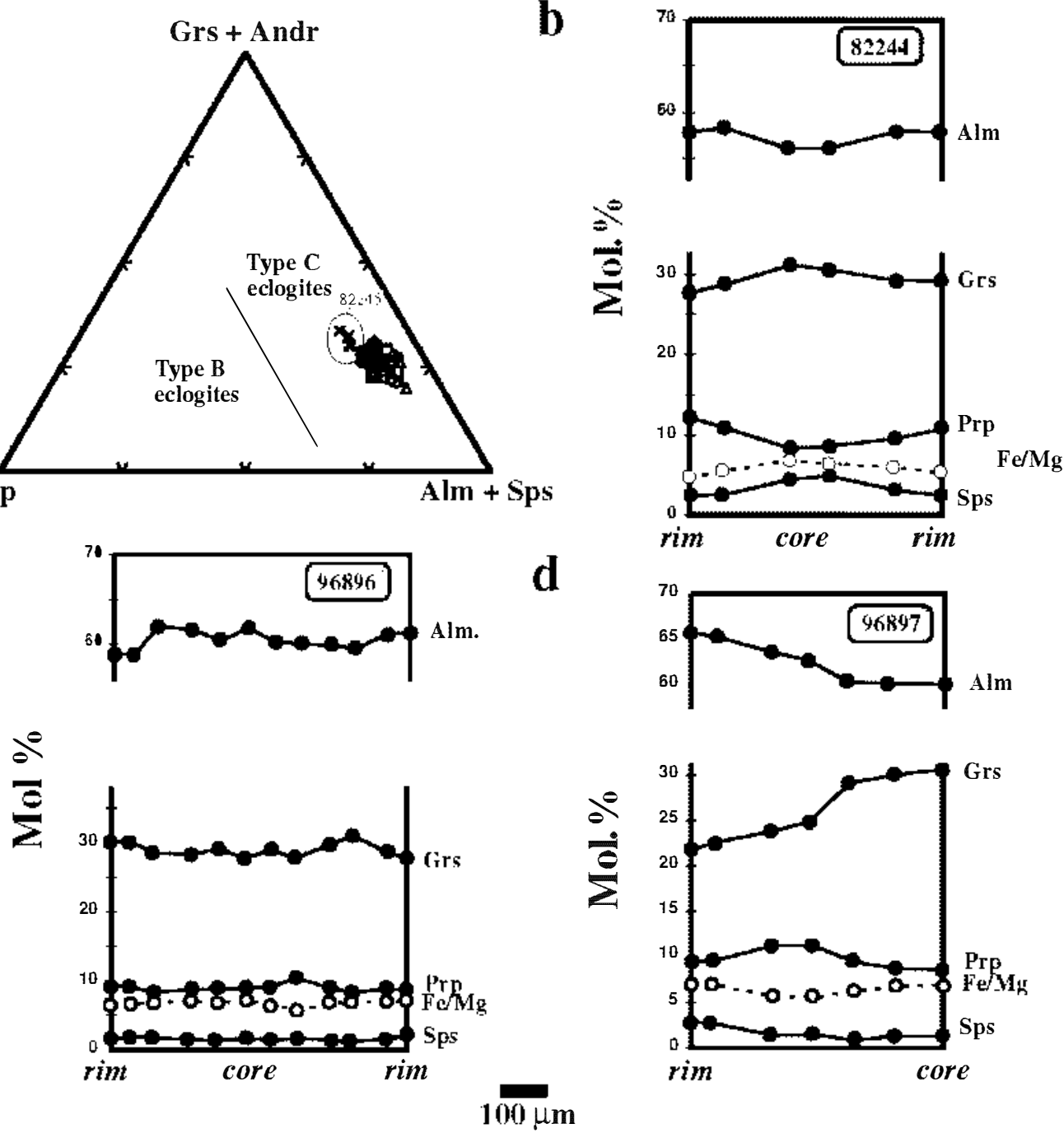

FIG. 3. (a) Garnet composition plot in the Prp-(Grs+Andr)-(Alm+Sps) diagram. Note the more calcic composition of the garnets in sample 82245. Fields of type B and C eclogites after Coleman et al. (1965). (b) Typical unzoned garnet profile in sample 96896. $(c, d)$ Zoning profiles with an increase in Fe accompanied by a decrease in Ca from core to rim indicating a down pressure re-equilibration.

calculated according to Robinson et al. (1982) and the amphiboles are classified according to Leake et al. (1997), (Table 4) All analysed amphibolcs are calcic types varying from hastingsite to ferropargasite in the most basic types and from magncsiohustingsitc to pargasitc and edenite in the most evolved metagabbros (Fig. 5, samplics 82244-5) (ierterally, the amphiboles included in garnet tend to show more magnesian compositions when comparcd to those in the matrix
(Fig. 5). This could be the result of local reequilibration due to the large volume differences between the host garnet and the amphibolc inclusion as stated by Spear (1991) for biotite inclusions in garnet from metapelitic rocks. The amphibolcs included in garnet display a slightly higher $\mathrm{Al}$ content in comparison with those of the matrix (Fig. 5). This tendency is reflecting progressive down-pressure amphibole recrystallization as will be discussed below. No stgnifkant 

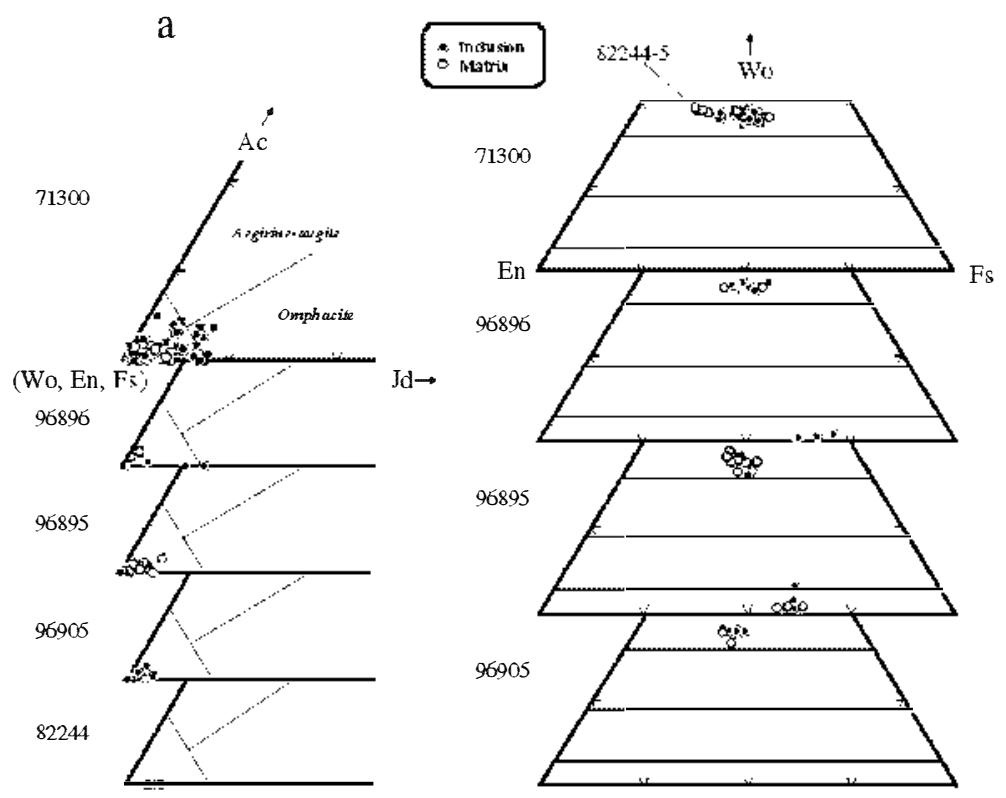

FIG. 4. (a) Clinopyroxene composition in terms of jadeite-aegirine-Q(di, en, fs); in samples 71300 and 96896 some clinopyroxene inclusions plot in the field of omphacite. (b) wollastonite-enstatite-ferrosilite classification diagram for clino- and orthopyroxenes.

chemical variation has been found in amphibole composition irrespective of its location in relation to garnet domains. When comparing the amphibole composition with that of other amphiboles from different metamorphic regimes we note that they plot in the field of intermediate pressure terrains (Fig. 5). This points to a retrogression during intermediate to lower pressure conditions as is common in other Hercynian eclogites (Messiga et al. 1992; Medaris et al, 1995).

\section{Plagioclase}

Most of the plagiaclase is found defining coronas around garnet, thus suggesting a post-eclogitic character (Fig. 2). Nevertheless, three textural types of plagioclase were distinguished: inclusions, coronas and matrix. Plagioclase presents similar compositions from sample to sample but in certain cases a wide range of variation within individual rocks occurs. In general, plitgioclasc composition varies from $A n_{10}$ to $A n_{50}$ the average being $\mathrm{An}_{20}$. The orthoclase content never exceeds $1 \mathrm{~mol} \%$. In gabbroic sample 71300, the plagio- clase included in garnet showed the highest albite content but nevertheless, its composition varies within a narrow range $\left(A n_{10}\right.$ to $\left.A n_{22}\right)$. In contrast, sample 96895 shows plagioclase with a wide compositional variation $\left(A n_{50}\right.$ to $A n_{10}$ ), the most calcic being that included in gamet. In the last two cases, plaginclasc inclusions are the result of the retrograde reaction between eclogitic garnet and clinopyroxene as evidenced by the presence of residual clinopyroxene surrounded by plagioclase coronas inside the garnet (see 1 -jg. $2 d$ ). In two samples, a compositional profile from the contact with the garnet towards the amphibolitic matrix has been performed, the plagioclase heing $\mathrm{An}_{45}$ against garnet and $\mathrm{An}_{28}$ towards the matrix. This coincides with the decrease in grossular component in the parnct rims, thus corlimming the downpressure re-equilibrium between garnet rims and adjacent plagioclase. This high An content of plagioulase between garnet and amphibole has been observed in other Herynian retrocilogites (O’Brien et al., 1992)

In every sample, plagioclase in the matrix presents similar compositions to the plagioutises 
TABLE 3. Selected clinopyroxene and orthopyroxene analyses from tholeiitic metabasites from the Sierra de Guadarrama.

\begin{tabular}{|c|c|c|c|c|c|c|c|c|c|c|c|c|c|c|c|c|c|c|c|}
\hline \multirow[b]{2}{*}{$\begin{array}{l}\text { Sample } \\
\text { Texture } \\
\text { Analy sis }\end{array}$} & \multicolumn{13}{|c|}{ Clinopyroxene } & \multicolumn{6}{|c|}{ Orthopyroxene } \\
\hline & $\begin{array}{c}71300 \\
\text { incl. } \\
61\end{array}$ & $\begin{array}{c}71300 \\
\text { incl. } \\
62\end{array}$ & $\begin{array}{c}71300 \\
\text { incl. } \\
105(\mathrm{c} 3)\end{array}$ & $\begin{array}{c}71300 \\
\text { incl. } \\
92\end{array}$ & $\begin{array}{c}71300 \\
\text { matrix } \\
101\end{array}$ & $\begin{array}{c}71300 \\
\text { matrix } \\
105\end{array}$ & $\begin{array}{c}96895 \\
\text { incl. } \\
53\end{array}$ & $\begin{array}{c}96895 \\
\text { incl. } \\
54\end{array}$ & $\begin{array}{c}96895 \\
\text { matrix } \\
79\end{array}$ & $\begin{array}{c}96895 \\
\text { matrix } \\
28\end{array}$ & $\begin{array}{c}96896 \\
\text { incl } \\
154\end{array}$ & $\begin{array}{c}96896 \\
\text { incl. } \\
162\end{array}$ & $\begin{array}{c}96896 \\
\text { matrix } \\
151\end{array}$ & 96895 & $\begin{array}{c}96895 \\
34\end{array}$ & $\begin{array}{c}96896 \\
\text { incl. } \\
38\end{array}$ & $\begin{array}{c}96896 \\
\text { incl. } \\
39\end{array}$ & 96896 & 96896 \\
\hline $\mathrm{SiO}_{2}$ & 50.65 & 51.01 & 52.24 & 51.80 & 50.90 & 49.93 & 50.40 & 50.76 & 52.02 & 51.47 & 52.84 & 50.66 & 50.42 & 49.60 & 50.04 & 50.55 & 50.44 & 48.51 & 49.22 \\
\hline $\mathrm{TiO}_{2}$ & 0.43 & 0.33 & 0.33 & 0.31 & 0.13 & 0.08 & 0.27 & 0.26 & 0.08 & 0.14 & 0.10 & 0.03 & 0.12 & 0.05 & 0.03 & 0.00 & 0.00 & 0.11 & 0.06 \\
\hline $\mathrm{Al}_{2} \mathrm{O}_{3}$ & 5.37 & 5.26 & 4.88 & 5.30 & 3.54 & 2.02 & 2.04 & 1.50 & 2.70 & 3.84 & 6.82 & 7.00 & 0.86 & 0.42 & 0.42 & 0.43 & 0.24 & 0.40 & 0.42 \\
\hline $\mathrm{FeO}$ & 14.93 & 14.73 & 14.68 & 15.22 & 14.81 & 19.72 & 16.77 & 14.76 & 14.35 & 12.00 & 11.93 & 15.45 & 18.18 & 36.74 & 35.36 & 36.33 & 36.08 & 39.06 & 37.88 \\
\hline $\mathrm{MnO}$ & 0.16 & 0.23 & 0.13 & 0.00 & 0.08 & 0.00 & 0.26 & 0.21 & 0.04 & 0.14 & 0.22 & 0.35 & 0.40 & 0.59 & 0.52 & 0.41 & 0.53 & 1.03 & 0.80 \\
\hline $\mathrm{MgO}$ & 7.23 & 7.30 & 7.49 & 6.88 & 9.46 & 7.23 & 8.60 & 9.96 & 10.06 & 10.03 & 7.44 & 5.99 & 7.87 & 12.37 & 11.56 & 12.21 & 12.37 & 9.15 & 10.62 \\
\hline $\mathrm{CaO}$ & 17.71 & 17.35 & 17.90 & 18.95 & 21.48 & 21.04 & 21.43 & 21.98 & 20.32 & 20.04 & 17.75 & 18.17 & 21.13 & 0.64 & 0.86 & 0.62 & 0.58 & 0.96 & 0.70 \\
\hline $\mathrm{Na}_{2} \mathrm{O}$ & 2.77 & 2.90 & 2.48 & 2.59 & 0.81 & 0.65 & 0.29 & 0.04 & 1.05 & 1.67 & 2.66 & 1.98 & 0.46 & 0.00 & 0.02 & 0.11 & 0.00 & 0.00 & 0.03 \\
\hline Total & 99.33 & 99.18 & 100.12 & 101.05 & 101.24 & 100.67 & 100.08 & 99.52 & 100.64 & 99.34 & 99.83 & 99.66 & 99.50 & 100.60 & 98.85 & 100.73 & 100.28 & 99.21 & 99.73 \\
\hline \multicolumn{20}{|c|}{ Structural formula $O=6$} \\
\hline $\mathrm{Si}$ & 1.93 & 1.94 & 1.97 & 1.94 & 1.91 & 1.93 & 1.95 & 1.96 & 1.96 & 1.94 & 1.97 & 1.93 & 1.97 & 1.97 & 2.00 & 2.00 & 2.00 & 1.99 & 1.99 \\
\hline $\mathrm{Al}^{\mathrm{IV}}$ & 0.07 & 0.06 & 0.03 & 0.06 & 0.09 & 0.07 & 0.05 & 0.04 & 0.04 & 0.06 & 0.03 & 0.07 & 0.03 & 0.02 & 0.00 & 0.00 & 0.00 & 0.01 & 0.01 \\
\hline $\mathrm{Ti}$ & 0.01 & 0.01 & 0.01 & 0.01 & 0.00 & 0.00 & 0.01 & 0.01 & 0.00 & 0.00 & 0.00 & 0.00 & 0.00 & 0.00 & 0.00 & 0.00 & 0.00 & 0.00 & 0.00 \\
\hline $\mathrm{Al}^{\mathrm{VI}}$ & 0.17 & 0.18 & 0.19 & 0.18 & 0.07 & 0.02 & 0.04 & 0.02 & 0.08 & 0.11 & 0.27 & 0.25 & 0.01 & 0.00 & 0.02 & 0.02 & 0.01 & 0.01 & 0.01 \\
\hline $\mathrm{Fe}^{3+}$ & 0.08 & 0.08 & 0.00 & 0.05 & 0.07 & 0.09 & 0.02 & 0.01 & 0.03 & 0.06 & 0.00 & 0.00 & 0.05 & 0.05 & 0.00 & 0.00 & 0.00 & 0.00 & 0.00 \\
\hline $\mathrm{Fe}^{2+}$ & 0.40 & 0.40 & 0.46 & 0.43 & 0.40 & 0.55 & 0.52 & 0.47 & 0.42 & 0.32 & 0.37 & 0.49 & 0.55 & 1.18 & 1.19 & 1.20 & 1.20 & 1.34 & 1.28 \\
\hline $\mathrm{Mn}^{2+}$ & 0.01 & 0.01 & 0.00 & 0.00 & 0.00 & 0.00 & 0.01 & 0.01 & 0.00 & 0.00 & 0.01 & 0.01 & 0.01 & 0.02 & 0.02 & 0.01 & 0.02 & 0.04 & 0.03 \\
\hline $\mathrm{Mg}$ & 0.41 & 0.41 & 0.42 & 0.39 & 0.53 & 0.42 & 0.49 & 0.57 & 0.56 & 0.56 & 0.41 & 0.34 & 0.46 & 0.73 & 0.69 & 0.72 & 0.73 & 0.56 & 0.64 \\
\hline $\mathrm{Ca}$ & 0.72 & 0.71 & 0.72 & 0.76 & 0.87 & 0.87 & 0.89 & 0.91 & 0.82 & 0.81 & 0.71 & 0.74 & 0.88 & 0.03 & 0.04 & 0.03 & 0.02 & 0.04 & 0.03 \\
\hline $\mathrm{Na}$ & 0.20 & 0.21 & 0.18 & 0.19 & 0.06 & 0.05 & 0.02 & 0.00 & 0.08 & 0.12 & 0.19 & 0.15 & 0.03 & 0.00 & 0.00 & 0.01 & 0.00 & 0.00 & 0.00 \\
\hline \multicolumn{20}{|c|}{ End-members } \\
\hline QUAD & 78.90 & 78.01 & 81.62 & 80.74 & 93.80 & 94.99 & 97.78 & 99.69 & 92.19 & 87.42 & 79.51 & 84.35 & 96.44 & & & & & & \\
\hline $\mathrm{Jd}$ & 14.16 & 15.44 & 18.38 & 15.14 & 3.17 & 1.01 & 1.38 & 0.22 & 5.54 & 8.44 & 20.49 & 15.65 & 0.60 & & & & & & \\
\hline Aegirine & 6.94 & 6.55 & 0.00 & 4.12 & 3.02 & 3.99 & 0.84 & 0.09 & 2.27 & 4.15 & 0.00 & 0.00 & 2.96 & & & & & & \\
\hline En & & & & & & & & & & & & & & 36.54 & 35.77 & 36.71 & 37.11 & 28.31 & 32.35 \\
\hline Fs & & & & & & & & & & & & & & 62.11 & 62.31 & 61.95 & 61.95 & 69.56 & 66.11 \\
\hline Wo & & & & & & & & & & & & & & 1.36 & 1.92 & 1.34 & 1.34 & 2.14 & 1.54 \\
\hline
\end{tabular}


TABLE 4. Selected amphibole analyses of tholeiitic metabasites from the Sierra de Guadarrama.

\begin{tabular}{|c|c|c|c|c|c|c|c|c|c|c|}
\hline Sample & 71300 & 71300 & 71300 & 71300 & $\begin{array}{l}71300 \\
\text { Inclusion }\end{array}$ & 96895 & 96895 & 96897 & 96897 & 96987 \\
\hline Analysis & 4 & 25 & 17 & 24 & 116 & 14 & 65 & 72 & 107 & 108 \\
\hline $\mathrm{SiO}_{2}$ & 43.27 & 40.10 & 40.28 & 40.58 & 40.36 & 42.96 & 42.06 & 44.79 & 43.47 & 43.12 \\
\hline $\mathrm{TiO}_{2}$ & 1.91 & 1.35 & 1.23 & 1.01 & 1.98 & 0.82 & 0.10 & 1.19 & 1.04 & 0.52 \\
\hline $\mathrm{Al}_{2} \mathrm{O}_{3}$ & 9.24 & 13.75 & 12.05 & 13.61 & 12.42 & 13.69 & 13.03 & 9.04 & 10.60 & 11.20 \\
\hline $\mathrm{FeO}$ & 17.96 & 20.40 & 21.85 & 20.84 & 23.27 & 18.58 & 23.81 & 19.60 & 20.91 & 20.52 \\
\hline $\mathrm{MnO}$ & 0.00 & 0.24 & 0.20 & 0.14 & 0.24 & 0.19 & 0.64 & 0.24 & 0.19 & 0.14 \\
\hline $\mathrm{MgO}$ & 10.57 & 7.23 & 7.16 & 7.10 & 5.92 & 7.08 & 5.30 & 9.02 & 7.93 & 8.01 \\
\hline $\mathrm{CaO}$ & 10.71 & 11.44 & 10.91 & 10.58 & 9.62 & 10.49 & 11.71 & 10.81 & 11.06 & 11.28 \\
\hline $\mathrm{Na}_{2} \mathrm{O}$ & 2.69 & 2.99 & 3.00 & 3.24 & 3.05 & 2.37 & 0.24 & 1.88 & 2.14 & 1.98 \\
\hline $\mathrm{K}_{2} \mathrm{O}$ & 0.14 & 0.23 & 0.00 & 0.00 & 0.18 & 0.14 & 0.09 & 0.05 & 0.03 & 0.04 \\
\hline Total & 96.49 & 97.73 & 96.68 & 97.09 & 97.03 & 96.32 & 96.98 & 96.63 & 97.35 & 96.81 \\
\hline \multicolumn{11}{|c|}{ Structural formula $13-\mathrm{CNK}$} \\
\hline TSi & 6.51 & 6.11 & 6.20 & 6.17 & 6.18 & 6.50 & 6.37 & 6.74 & 6.56 & 6.52 \\
\hline $\mathrm{TAl}$ & 1.49 & 1.89 & 1.80 & 1.83 & 1.82 & 1.50 & 1.63 & 1.26 & 1.44 & 1.48 \\
\hline Total T & 8.00 & 8.00 & 8.00 & 8.00 & 8.00 & 8.00 & 8.00 & 8.00 & 8.00 & 8.00 \\
\hline $\mathrm{CAl}$ & 0.15 & 0.57 & 0.38 & 0.61 & 0.41 & 0.94 & 0.69 & 0.34 & 0.44 & 0.52 \\
\hline $\mathrm{CFe}^{3+}$ & 0.00 & 0.35 & 0.00 & 0.00 & 0.86 & 0.26 & 1.03 & 0.60 & 0.57 & 0.59 \\
\hline $\mathrm{CTi}$ & 0.22 & 0.15 & 0.14 & 0.12 & 0.23 & 0.09 & 0.01 & 0.13 & 0.12 & 0.06 \\
\hline $\mathrm{CMg}$ & 2.37 & 1.64 & 1.64 & 1.61 & 1.35 & 1.60 & 1. 20 & 2.02 & 1.78 & 1.81 \\
\hline $\mathrm{CFe}^{2+}$ & 2.26 & 2.25 & 2.81 & 2.65 & 2. 12 & 2.09 & 1. 99 & 1.86 & 2.07 & 2.00 \\
\hline CMn & 0.00 & 0.03 & 0.03 & 0.02 & 0.03 & 0.02 & 0.08 & 0.03 & 0.02 & 0.02 \\
\hline Total C & 5.00 & 5.00 & 5.00 & 5.00 & 5.00 & 5.00 & 5.00 & 5.00 & 5.00 & 5.00 \\
\hline $\mathrm{BCa}$ & 1.73 & 1.87 & 1.80 & 1.72 & 1.58 & 1.70 & 1. 90 & 1.74 & 1.79 & 1.83 \\
\hline $\mathrm{BNa}$ & 0.27 & 0.13 & 0.20 & 0.28 & 0.42 & 0.30 & 0.07 & 0.26 & 0.21 & 0.17 \\
\hline Total B & 2.00 & 2.00 & 2.00 & 2.00 & 2.00 & 2.00 & 1.97 & 2.00 & 2.00 & 2.00 \\
\hline $\mathrm{ANa}$ & 0.51 & 0.75 & 0.69 & 0.68 & 0.48 & 0.39 & 0.00 & 0.29 & 0.41 & 0.41 \\
\hline $\mathrm{AK}$ & 0.03 & 0.04 & 0.00 & 0.00 & 0.03 & 0.03 & 0.02 & 0.01 & 0.00 & 0.01 \\
\hline Total A & 0.54 & 0.79 & 0.69 & 0.68 & 0.52 & 0.42 & 0.02 & 0.30 & 0.42 & 0.42 \\
\hline Total & 15.54 & 15.79 & 15.69 & 15.68 & 15.52 & 15.42 & 14.99 & 15.30 & 15.42 & 15.42 \\
\hline
\end{tabular}

of the inclusions and coronas. As previously, a tendency towards more calcic composition close to the garnet domain is seen.

\section{Whole-rock chemistry and petrogenesis of the metabasite protoliths}

The major and trace elements of nine metabasites are given in Table 5. Three samples are taken from Villaseca (1983) with new trace and $R E E$ and yocs carried out at the CRPG-CNRS (Nancy, France)

The analysed metabasites range in composition from gabbro to leucotonalitc showing a lasge degree of differentiation, the most variable types being those cropping out at Tenzuela massif (Fig. 1) (Villaseca, 1983). In other outcrops the metagabbroic composition dominates. The CIPW normative compositions range from olivinenormative ( $<15 w$ t. ${ }^{j} / \mathrm{s}$ ) in the gabbros towards yuartz-normative for rocks with $\mathrm{SiO}_{2}$ contents of $>49 \mathrm{wt} \%$. The metabasic series vary from silica saturated to oversaturated. The most differentiated rock (leucotonalite 67041, Table 5) has up to 0.51 wt. $\%$ normative corundum. The subalkaline chemical composition together with their very low $\mathrm{K}_{2} \mathrm{O}$ content defines a tholeiitic affinity for these metabasites. This tholeiitic character is also 

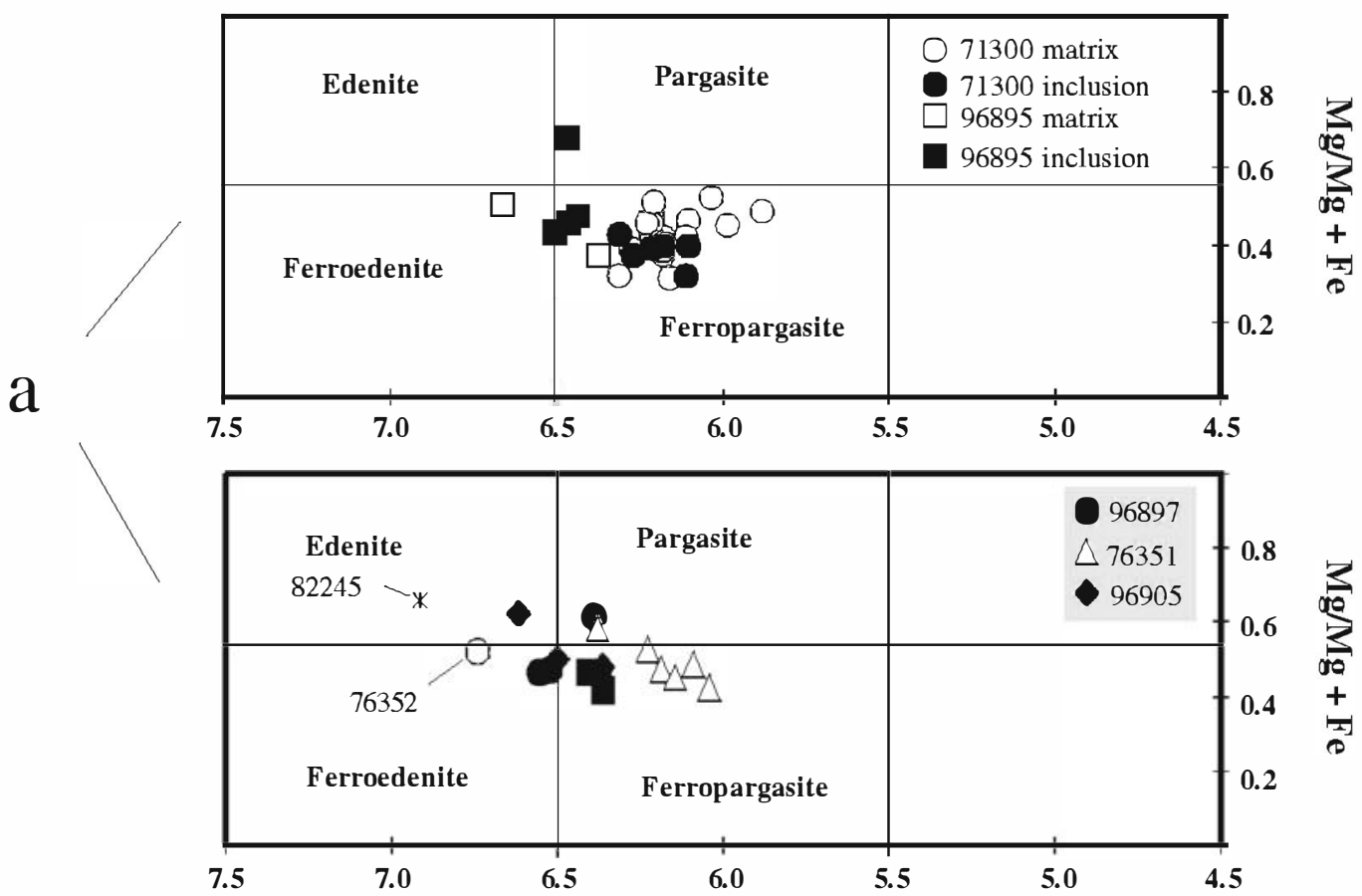

Si (p.f. u.)

b
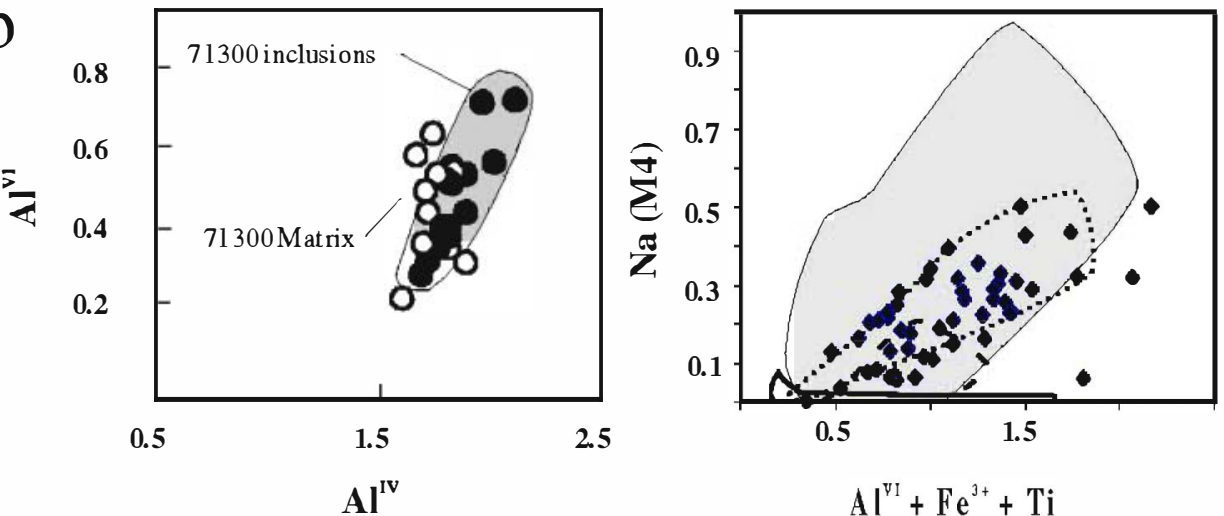

FIG. 5. (a) Composition of Ca-amphiboles from the Central Spain metabasites (Leake et al., 1997); (b) concentration of $\mathrm{Al}$ in four and six fold coordinates sites for inclusion and matrix amphiboles of sample 71300; $(c) \mathrm{Na}\left(\mathrm{M}_{4}\right)$ vs. $\mathrm{Al}^{\mathrm{VI}}+\mathrm{Fe}^{3+}+\mathrm{Ti}$ diagram of amphiboles from Central Spain metabasites compared to amphiboles of different metamorphic facies series. Shaded field: Sanbagawa and Franciscan high pressure facies series; dotted line: Dalradian intermediate pressure facies; continuous line: Haast River intermediate pressure facies; dashed line: Abukuma low pressure terrane; from Laird and Albee (1981).

shown by the high Fe content of the metabasites in the AFM diagram (Fig. 6a). The $\mathrm{P}_{2} \mathrm{O}_{5}$ contents are generally high compared to other tholeiitic series. In fact, in the $\mathrm{MnO}-\mathrm{TiO}_{2}-\mathrm{P}_{2} \mathrm{O}_{5}$ diagram (Fig. 6b) these metabasites plot from tholeiitic towards more alkaline fields (Mullen, 1983).
The HFSE and REE are usually regarded as trace elements remaining unaffected by metamorphic processes (Rollinson, 1993). All the analysed metabasites are richer in $\mathrm{Th}, \mathrm{Nb}, \mathrm{Zr}$ and LILE than averaged MORB composition (Fig. 6c). In fact, in the $\mathrm{Zr} / \mathrm{Y}$ vs. $\mathrm{Zr}$ diagram (not shown), 

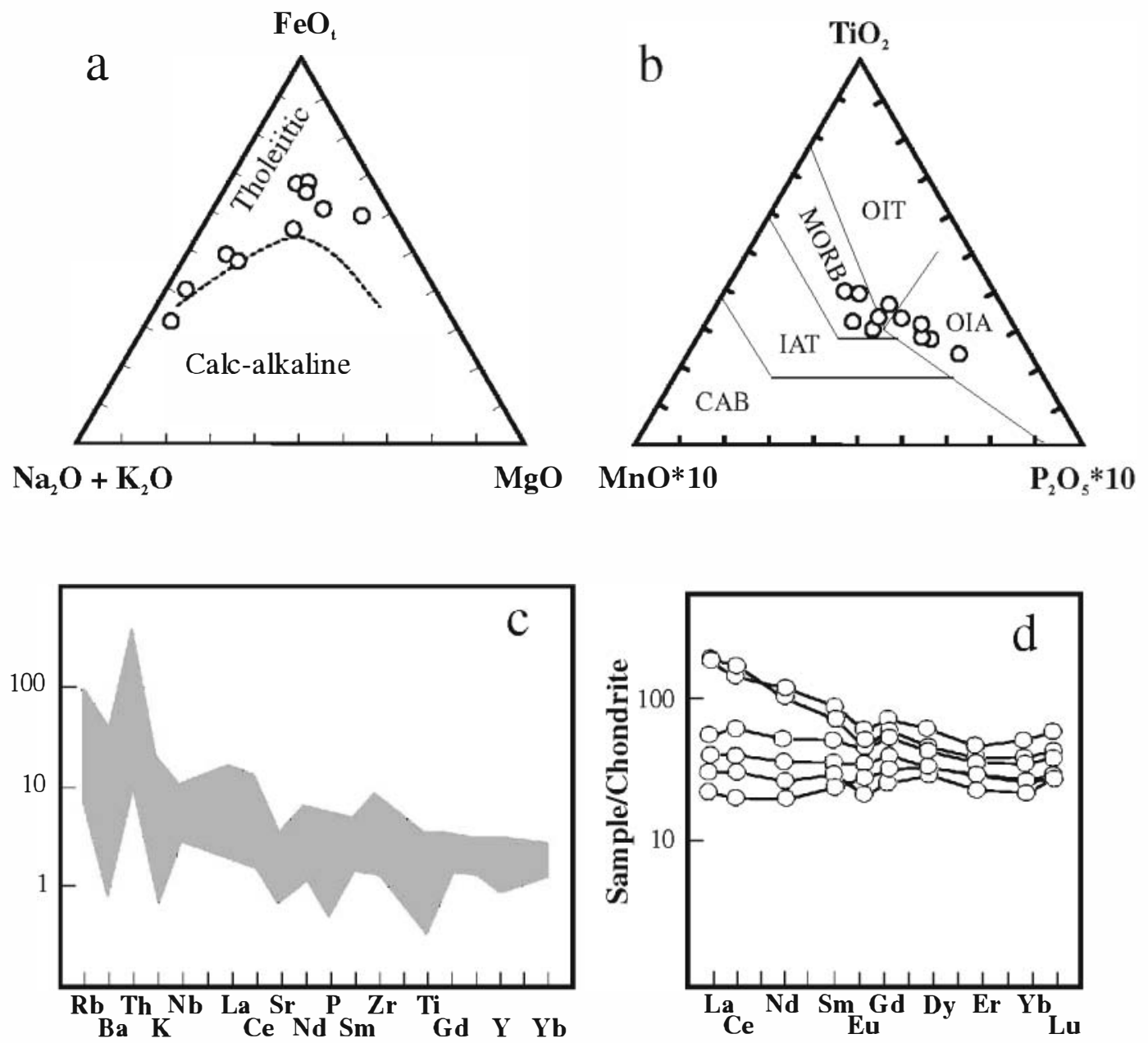

FIG. 6. (a) AFM diagram for the Central Spain metabasites showing the typical Fe enrichment of the tholeiitic series; fields after Irvine and Baragar (1971). (b) $\mathrm{MnO}-\mathrm{TiO}_{2}-\mathrm{P}_{2} \mathrm{O}_{5}$ discrimination diagram with fields after Mullen (1983). (c) N-type MORB (Saunders and Tarney, 1984; Sun, 1980) normalized diagram for metabasites; CAB, island-arc calc-alkaline basalt; IAT, island-arc tholeiite; OIT, ocean-island tholeiite; OIA, ocean-island alkali basalt. $(d) \mathrm{Cl}$ chondrite (Evensen et al., 1978) normalized REE diagram.

these metabasites plot mostly in within-plate fields, far from the composition of oceanic or platemargin basalts (Pearce and Norry, 1979). Although the metagabbros varieties exhibit flat chondritenormalized $R E E$ patterns $\left(\mathrm{La}_{\mathbf{N}} / \mathrm{Yb}_{\mathrm{N}}=1.0-1.8\right)$ they show absolute concentrations of $\sim 20$ times chondrite (Fig. 6d). The more silica-rich metabasites display $L R E E$-enriched pattems $\left(\mathrm{La}_{\mathrm{N}} / \mathrm{Yb}_{\mathrm{N}}=\right.$ 3.6) and some negative Eu anomaly, but $H R E E$ patterns are consistently flat suggesting that neither garnet nor amphibole were important phases involved in the petrogenesis of the tholeiites.

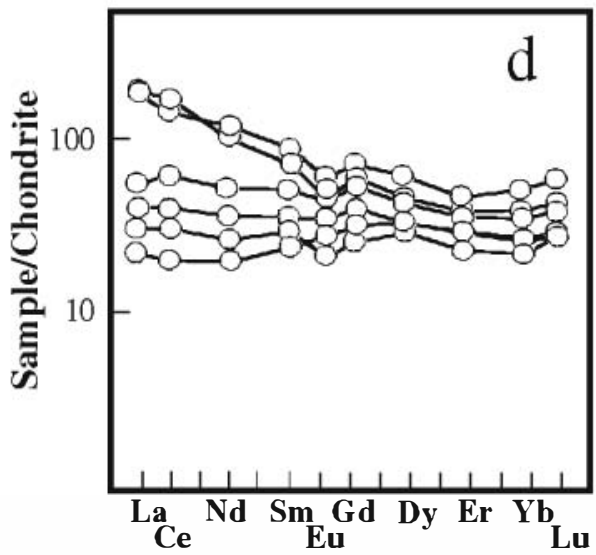

In summary, we believe that the metabasic protolith derived from low-pressure crystal fractionation of tholeiitic melts more enriched than typical MORB compositions. Their association with typical continental platform sediments such as mature pelites, calc-silicates, marbles and minor quarzites, defines a continental affinity and not an oceanic character for these tholeiitic sills. The high degree of evolution acquired by these metabasites is illustrated by the presence of felsic types which is in agreement with intracontinental scenarios proposed by Hess (1989) 
TABLE 5. Major and trace element analysis of selected metabasites.

\begin{tabular}{|c|c|c|c|c|c|c|c|c|c|c|}
\hline Sample & 71300 & 96895 & 96896 & 62984 & 71303 & 82244 & 9512 & 66726 & 67056 & 67041 \\
\hline $\mathrm{SiO}_{2}$ & 44.41 & 46.34 & 48.23 & 48.60 & 49.50 & 50.43 & 51.79 & 63.92 & 69.44 & 72.77 \\
\hline $\mathrm{TiO}_{2}$ & 4.36 & 3.81 & 3.46 & 2.89 & 2.22 & 1.94 & 1.93 & 1.28 & 0.58 & 0.43 \\
\hline $\mathrm{Al}_{2} \mathrm{O}_{3}$ & 13.02 & 12.82 & 13.12 & 14.73 & 13.59 & 13.43 & 14.14 & 14.11 & 13.68 & 14.36 \\
\hline $\mathrm{Fe}_{2} \mathrm{O}_{3}$ & 20.11 & 18.66 & 17.75 & 13.38 & 14.08 & 14.51 & 12.55 & 7.73 & 5.28 & 3.21 \\
\hline $\mathrm{MnO}$ & 0.40 & 0.31 & 0.28 & 0.22 & 0.27 & 0.23 & 0.22 & 0.08 & 0.04 & 0.03 \\
\hline $\mathrm{MgO}$ & 4.36 & 4.77 & 4.19 & 4.88 & 7.52 & 5.43 & 6.42 & 1.37 & 0.66 & 0.62 \\
\hline $\mathrm{CaO}$ & 9.51 & 9.54 & 8.95 & 8.13 & 10.53 & 10.64 & 10.50 & 4.64 & 3.3 & 2.43 \\
\hline $\mathrm{Na}_{2} \mathrm{O}$ & 3.56 & 3.33 & 3.39 & 3.53 & 1.27 & 2.94 & 1.70 & 5.72 & 5.08 & 5.49 \\
\hline $\mathrm{K}_{2} \mathrm{O}$ & 0.43 & 0.15 & 0.36 & 1.46 & 0.24 & 0.05 & 0.31 & 0.43 & 1.46 & 0.51 \\
\hline $\mathrm{P}_{2} \mathrm{O}_{5}$ & 0.32 & 0.45 & 0.52 & 0.64 & 0.26 & 0.12 & 0.25 & 0.29 & 0.2 & 0.06 \\
\hline LOI & 0.90 & 0 & 0 & 1.50 & 1.23 & 0.39 & 0.46 & 0.22 & 0.22 & 0.4 \\
\hline Total & 101.38 & 99.92 & 99.95 & 99.96 & 100.71 & 100.41 & 100.27 & 99.79 & 99.94 & 100.31 \\
\hline $\mathrm{Ba}$ & 123 & 25 & 67 & 129 & 241 & 28 & & 117 & 224 & 123 \\
\hline $\mathrm{Rb}$ & 10 & 4 & 15 & 54 & 5 & 9 & & 12 & 30 & 12 \\
\hline $\mathrm{Sr}$ & 61 & 62 & 76 & 136 & 87 & 109 & & 141 & 122 & 324 \\
\hline $\mathrm{Nb}$ & 15 & 12 & 15 & & & 7 & & 24 & 20 & \\
\hline $\mathrm{Zr}$ & 154 & 191 & 241 & 190 & 100 & 102 & & 541 & 665 & 564 \\
\hline $\mathrm{Y}$ & 42 & 50 & 63 & & 25 & 40 & & 91 & 74 & 53 \\
\hline Th & 5 & 1.3 & 1.84 & & 17 & 4 & & 14 & 15 & \\
\hline $\mathrm{Ga}$ & 29 & 22 & 24 & 24 & & 21 & & 27 & 26 & \\
\hline $\mathrm{La}$ & 4.91 & 9.06 & 13.04 & & & 7.09 & & 39.70 & 41.72 & \\
\hline $\mathrm{Ce}$ & 12.23 & 23.01 & 36.66 & & & 17.72 & & 83.77 & 98.07 & \\
\hline $\mathrm{Nd}$ & 8.79 & 16.33 & 24.61 & & & 11.89 & & 50.18 & 45.78 & \\
\hline $\mathrm{Sm}$ & 3.78 & 5.25 & 7.9 & & & 4.43 & & 13.28 & 11.37 & \\
\hline $\mathrm{Eu}$ & 1.55 & 1.8 & 2.52 & & & 1.23 & & 3.36 & 2.22 & \\
\hline $\mathrm{Gd}$ & 6.46 & 7.52 & 9.59 & & & 5.20 & & 12.96 & 11.13 & \\
\hline Dy & 8.28 & 8.32 & 10.96 & & & 6.22 & & 14.58 & 11.46 & \\
\hline $\mathrm{Er}$ & 3.76 & 4.8 & 6.14 & & & 3.33 & & 7.55 & 6.86 & \\
\hline $\mathrm{Yb}$ & 3.89 & 4.51 & 5.88 & & & 3.73 & & 8.70 & 6.66 & \\
\hline $\mathrm{Lu}$ & 0.68 & 0.74 & 0.93 & & & 0.67 & & 1.46 & 1.05 & \\
\hline
\end{tabular}

\section{P-T conditions}

For kinetic reasons, mafic rocks tend to preserve high-pressure parageneses relative to felsic rocks (O'Brien et al., 1992) The presence of scarce onplacilic pyro xenc included in garnet in certain samples indicates that the $P-T$ evolution of these rocks passed through a high $P$ stage.

$\mathrm{M}_{2}$ granulitic re-crystallizationis proven by the presence of pliagioclase coronas around clinopyroxene inclusions in garnet (Fig. 2). This indicates the occurrence of the reaction:

$$
\mathrm{Grt}+\mathrm{Onmp} \rightarrow \mathrm{Pl}(<\mathrm{An})+\mathrm{Cpx}(\text { low Na) }
$$

instead of reactions involving quartz (e.g. GADS, O'Brien et al., 1992) as these metagabbros present an olivine-normative composition.
Reaction 1 marks the transition from eclogite to granulite facies conditions.

The witespread presence of plagioclase and pargasitic amphibole coronas around garnet and the general amphibolitization of the rock (Fig. 2) as $\mathrm{H}_{2} \mathrm{O}$ pressure increases are controlled by reactions such as:

$$
\mathrm{Grt}+\mathrm{Cpx} \rightarrow \mathrm{Pl}(>\mathrm{An})+\mathrm{Amp}
$$

(Spear, 1993 ) which is atso typical of the $\mathrm{M}_{2}$ metamorphic re-crystallization episode. The local presence of orthopyroxene in the inner coronas around garnet (Fig. 2e) indicates a reaction of the form

$$
\mathrm{Grt}+\mathrm{C}_{\mathrm{px}}( \pm \mathrm{Qtz}) \rightarrow \mathrm{Opx}+\mathrm{Pl}
$$

which is less common than reaction 2 probably 
because of minor variations in the whole-rock composition of the metabasites and/or the presence of minor volatile phases during the eclogite retrogression. The last two reactions are probably coupled because: (1) the outer amphibole-rich rim is concentric to the orthpyroxene + plagioclase inner rim (Fig. 2e); and (2) both the orthopyroxene and the amphibole were formed during granulitic conditions as deduced from the $P-T$ estimates as discussed below.

This metamorphic evolution is represented in terms of ACF diagrams in Fig. 7. The tie-lines connecting Jd-rich clinopyroxene and garnet (eclogite paragenesis) switch to a new tie-line connecting $\mathrm{Ca}$-rich plagioclase and amphibole (reaction 2), and Na-rich plagioclase and diopsidic clinopyroxene (reaction 1). In certain microdomains of some metagabbros (sample 96895, Fig. 7) reaction 3 can take place together with reaction 2 with the new orthopyroxeneplagioclase assemblage formed in the inner zones towards the garnet (Fig. 2).

The peak pressure eclogitic conditions are documented by the paragenesis Alm-Grs-Prp garnet + omphacite + rutile + quartz.

Combination of the garnet-clinopyroxene Fe$\mathrm{Mg}$ exchange thermometer (Ellis and Green, 1979; Krogh, 1988) and the geobarometer based on the reaction: albite in plagioclase $=$ jadeite (in omphacite) + quartz (Holland, 1980) yields pressure-temperature conditions (Fig. 8) of $\sim 14 \pm 2 \mathrm{kbar}$ and $700 \pm 50^{\circ} \mathrm{C}$ (sample 71300), $12 \pm 2 \mathrm{kbar}$ and $675 \pm 50^{\circ} \mathrm{C}$ (sample 82244).
Inclusion omphacite and adjacent core garnet were used in all cases.

Pressure-temperature estimates have also been made using TWEEQU techniques as described by Berman (1991) using the end-member properties and thermodynamic database of Berman (1988; 1990). The solution models used in the calculations are from Berman (1990) for garnet; Fuhrman and Lindsley (1988) for plagioclase, and ideal models are used for pyroxenes. Reaction curves were calculated for the mineral compositions given in Tables $2-4$ and the assemblages deduced from petrographic studies (Table 1) considered to be representative of the first Hercynian metamorphic episode. Intersections giving standard deviations of \pm 0.5 bar and $\pm 20^{\circ} \mathrm{C}$ after no more than one iteration in the exclusion analysis are regarded as yielding acceptable results. Core-inclusions representing peak pressure conditions and border and matrix phases representative of the later retrogression stages are treated separately.

The eclogite-granulite transition paragenesis in sample 71300 with omphacitic pyroxene inclusions in garnet, produce a tight crossing of reactions (two independent) at pressures of $\sim 14 \mathrm{kbar}$ and temperatures of $\sim 760^{\circ} \mathrm{C}$ (Fig. 9). This is considered to represent the highest pressure attained in the area. Similar $P-T$ values are obtained, nevertheless, for other samples like 76352, 82244 and 96895 for equilibrium parageneses $\mathrm{Grt}+\mathrm{Pl}+\mathrm{Cpx}$ $+\mathrm{Qtz}+\mathrm{Ilm}+\mathrm{Rt}$ resulting in tight crossing of all equilibria(two independent)as illustrated in Fig. 9.
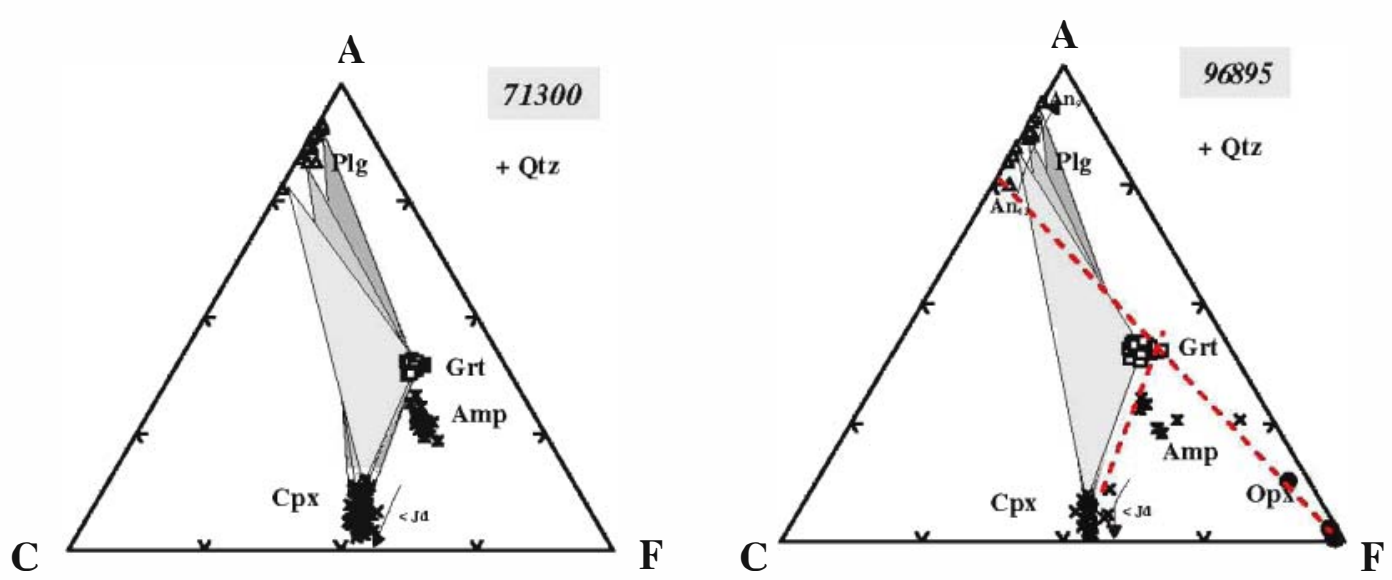

FIG. 7. ACF diagrams showing the tie-line switching from gnt-cpx (jd rich) assemblages toward a typical granulite facies paragenesis with plagioclase and amphibole and/or orthopyroxene. 


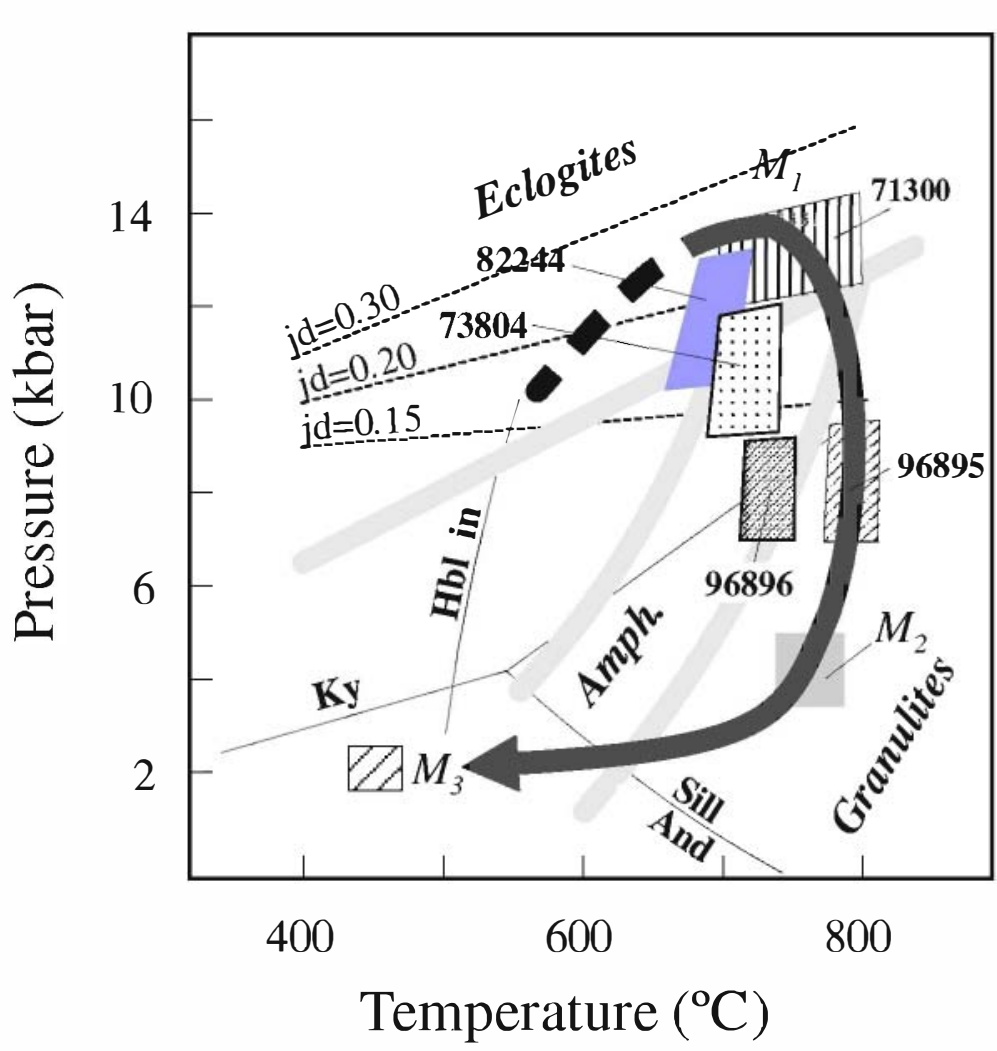

FIG. 8. $P T$ diagram in which the results of several classical thermobarometers in different samples (textured quadrangular areas with respective sample number) for the $M_{1}$ and $M_{2}$ metamorphic stages are shown. $M_{2}$ peak conditions from Martín Romera et al. (1999). $\mathrm{M}_{3}$ metamorphic conditions from Villaseca (1983) and Arenas et al., (1991). Thick grey arrow shows a possible PT metamorphic path for the Sierra de Guadarrama sector as deduced from the metamorphic conditions of the three main metamorphic stages. Jadeite isopleths are after Gasparik and Lindsley (1980); Hbl in reaction after Winkler (1976); Ky-And-Sill is after Holdaway (1971); facies boundaries drawn after Spear (1993).

Relics of high-pressure $M_{1}$ assemblages in the related layered metasedimentary sequence have also been identified (Villaseca, 1983; Villaseca and Barbero, 1994). These relics consist of kyanite, Mg-rich garnet $\left(\mathrm{Alm}_{63}-\mathrm{Pir}_{33}-\mathrm{Gros}_{3}-\right.$ $\mathrm{Sps}_{1}$ ), rutile and occasional staurolite from which pressure estimates of $\sim 8-15 \mathrm{kbar}$ for temperatures of $700 \pm 25^{\circ} \mathrm{C}$ have been reported (Villaseca and Barbero, 1994). So, the similarity of $P-T$ conditions deduced for the $M_{1}$ stage for both the paragneisses and the related metabasites indicates that the whole complex bas experienced the same burial history.

In metabasites with well-developed plagioclase coronas around garnet, it is possible to estimate core and rim conditions and a record of the two main re-crystallization episodes $M_{1}$ and $M_{2}$ is obtained. For example, calculations performed on sample 82244, for the equilibrium parageneses $\mathrm{Grt}+\mathrm{Pl}+\mathrm{Cpx}+\mathrm{Qtz}+\mathrm{Ilm}+\mathrm{Rt}$ with garnet core composition and $\mathrm{Cpx}, \mathrm{Plg}, \mathrm{Ilm}$ and Rt inclusions produce tight crossing of all equilibria at pressures in the range of $12-13 \mathrm{kbar}$ and $T$ in the range 700 to $750^{\circ} \mathrm{C}$. Results in the same sample for garnet rim compositions and matrix phases give $P-T$ conditions of $8 \mathrm{kbar}$ at temperatures of $\sim 700^{\circ} \mathrm{C}$. Similar decompressional $P-T$ paths are obtained for other samples thus confirming the validity of these calculations (Figs 8, 9). Temperature conditions obtained for the $\mathrm{M}_{2}$ episode, without taking amphibole into account in the calculations, are consistent with those deduced from the conventional garnetamphibole thermometer (Graham and Powell, 


\section{Cores and inclusions}
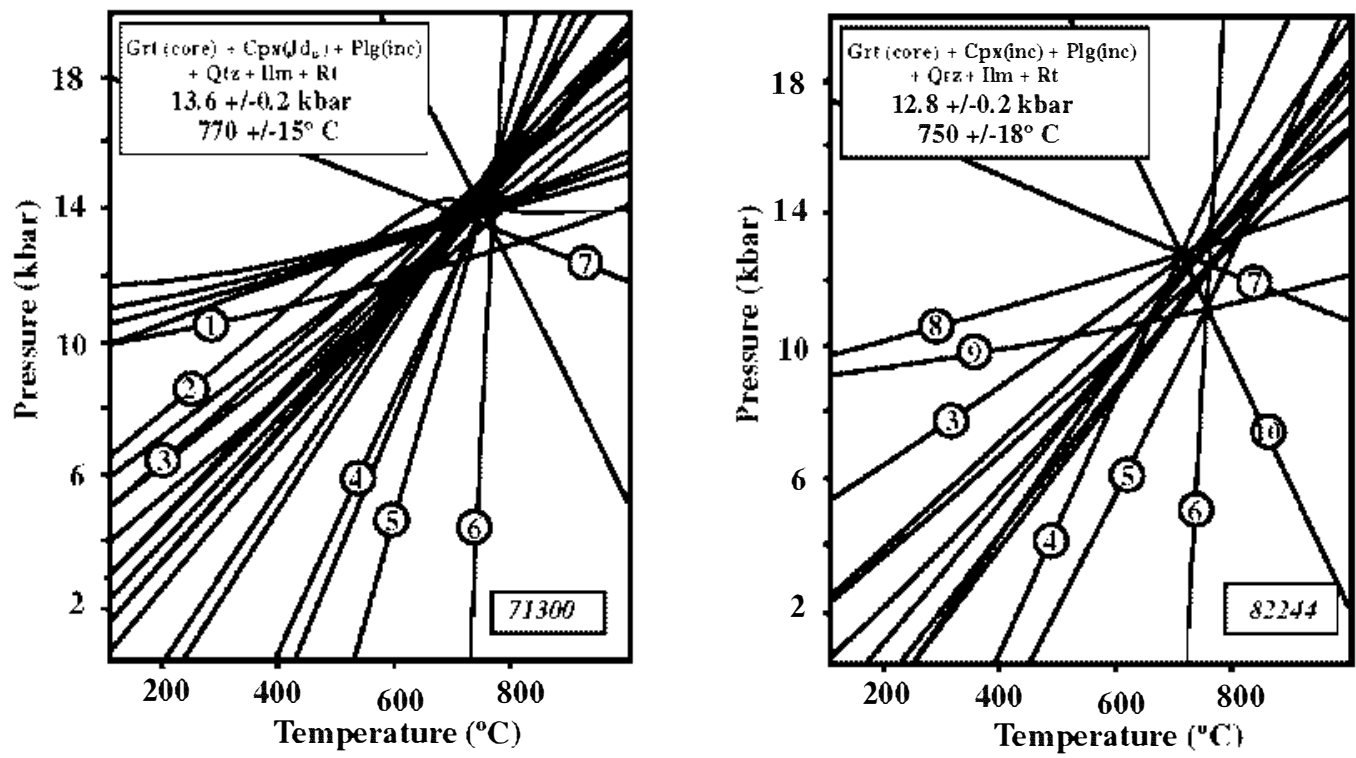

Rims and matrix
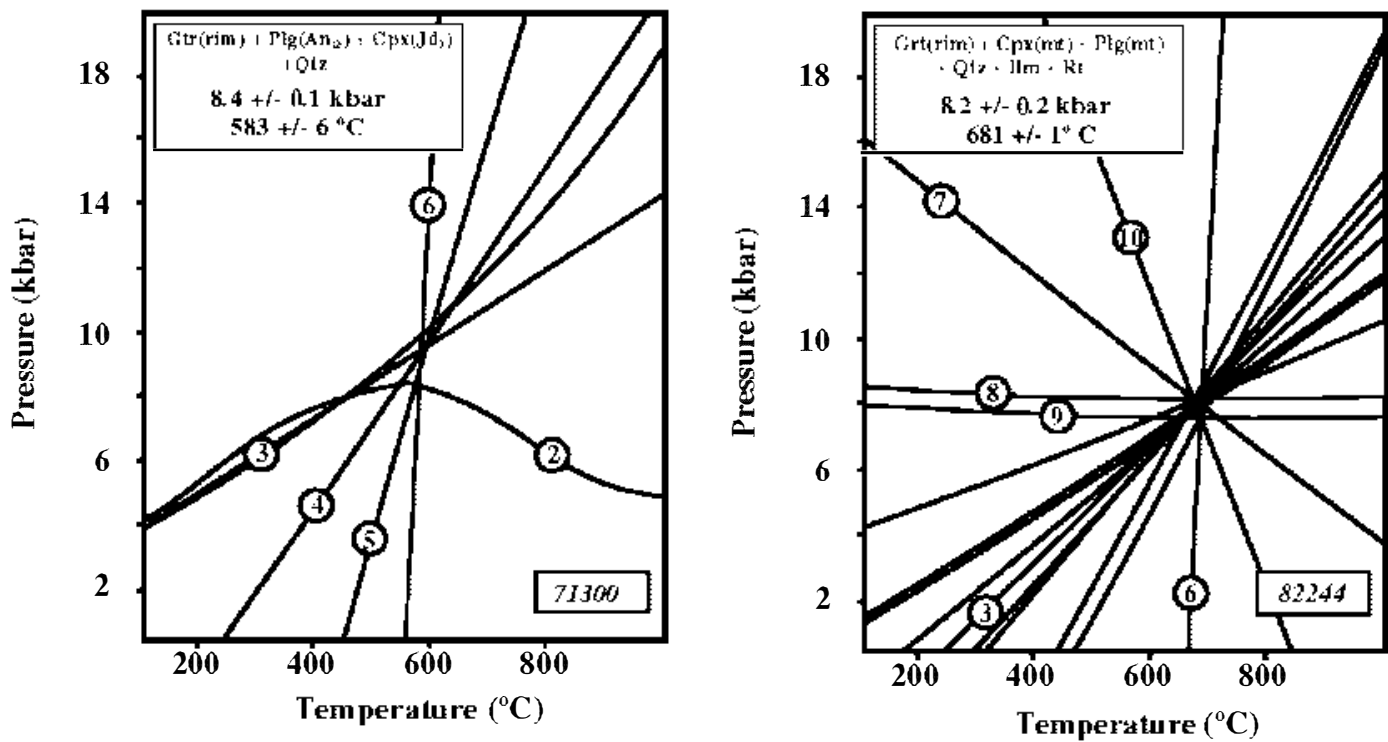

FIG. 9. $P T$ estimates based on the TWQ intersections for cores-inclusions and rims-matrix of individual samples using the mineral assemblages shown in the insets and some of the reactions (labelled) of the Appendix. See text for further details of the activity models used, thermodynamic data set and uncertainties of the intersections. 
1984) which give results in the range 680 to $750^{\circ} \mathrm{C}$. Similar results are obtained using the two pyroxene thermometer from Wood and Banno (1973) considering matrix phases $\left(800-850^{\circ} \mathrm{C}\right.$ in sample $96895,750-800^{\circ} \mathrm{C}$ in sample 96896 ) and also with the gamer-nthopyrome geothermometer from Harley (1984) considering garnet rims and adjacent matrix orthopyroxene (760-800 ${ }^{\circ}$, sample 96896). Pressures during the $\mathrm{M}_{2}$ episode must be $<7-8 \mathrm{kbar}$ as the jatleite. component in clinopyroxene is always $<10 \%$ Fig. 8) which is consistent with the results obtained using the internally consistent thermodynamic database as discussed above.

The related paragneisses enclosing the eclogitic metabasic lenses evolve cofacially with them, displaying $\mathrm{K}$-feldspar, biotite, cordierite, and sillimanite as part of a decompressive $\mathrm{M}_{2}$ paragenesis, whose path must clearly cross in to the sillimanite stability field (Fig. 8). Thermobarometric estimates based on garnet biotite and GASP equilibria give $T$ in the range $740-780^{\circ} \mathrm{C}$ and $P$ of $4-6 \mathrm{kbar}$ (Martín Romera et al, 1999), which is in agreement with the gritnulitic peak conditions estimated in the metabasites.

\section{Discussion}

High-pressure mineral assemilages reflecting the pesk pressure conditions in rocks from the axial Hcriynitan sectors are rcmarkably scarce. In the Hercynides from central $S_{\text {pain, the main remains }}$ of a high-pressure event are the rare omphacitic pyroxenesincluded in garnet described in this and previous works (Villaseca, 1983; Villaseca and Barbero, 1994). The first Hercynian tectonometamorphic phase recorded in the Spanish Central System is Devonian in age, and is marked by the interruption of Palaeozoic sedimentation (Gutiérrez Marcos et al., 1990). In coincidence with this assumption are the ages of $370-380 \mathrm{Ma}$ which Wildberg et al., (1989) obtained from zircon from different Iaragneisses and orthogneisses from the eastern part of the Sierra de Guadarrama and which they assume reflect the first Hcrcyrian comprcosive event $\left(D_{1}\right)$.

The metamorphic climax with associated crustal anatexis is estimated to have occurred at 325-330 Ma based on gcochronologicial data such as U-Pb in monazite from gnciss cs of the eastern part of the Sierra de Guadarrama (Valverde Vaquero et al., 1995; Escuder Viruete et al., 1998)
Peak pressure conditions based on the eclogitic relics in the metabasites studied in this work are estimated to be $\sim 14 \mathrm{kbar}$ and $750^{\circ} \mathrm{C}$. Pressuretemperature estimates made on garnet rims and matrix phases vary from 6 to $10 \mathrm{kbar}$ and 680 to $800^{\circ} \mathrm{C}$. As the metamorphic climax conditions of the area have been estimated to be at even lower pressures (4-6 kbar, Villaseca, 1983), the total decompression range has to be $\sim 8-10 \mathrm{kbar}$ (1ig. 8). The $P-T$ path thus obtained shows an isothermal decompression, and in any case, an important increase in temperature related to thermal relaxation is not observed. Such an isothermal deconpressicn requires unroofing of deep-placed metamorphic rock to be rapid compared to the rate of thermal relaxation and subsequent cooling, but not so rapid as to preserve abundant high-pressure relics. Whether the exhumation is related to extension of an overthickened and /or thermally weakened orogenic crust (Ridley, 1989; Ruppel and llndges, 1994) or thrusting acconplished by high rates of synorogenic erosion (Jamieson et al., 1995; Willett et al., 1993), or a combination of the two, is a difficult yucstion to answer with the present data. Nevertheless, the presence of a system of extensional detachments such as the BerzosaRiaza shear zones in the Sierra de Guadarra, (Escuder Viruete et al., 1998) suggests that the near isothermal decompression path could be largely controlled by these extensional tectonics. Rclativaly rapid extrusion uplift pcrmits the transition from the eclogite field to the sillimanite stability field. Isostatic erosion (England and Thompson, 1984) never reaches such a largescale advection of heat and the $P-T$ path never reaches the sillimanite field (Thompson et al, 1997). With the geochronological data available, this decompression has occurred during a time span of $\sim 40-50 \mathrm{Ma}$.

It is remarkable that these high-pressure metamorphic rocks occur in an intracontinental section of the Hcrcynian orogen, implying a litrgc thickening of the continental crust during the flercyrian collision. The new barometric estimates made in this work allow us to envisage a burial depth for these metabasites of $\sim 55 \mathrm{~km}$ (considering an average density for the crust in this sector of $\sim 2.7 \mathrm{~g} \mathrm{~cm}^{-3}$. laking into account that there is no evidence of important tectonic imbrication of different custal slices since Hercyrian times, and that the present thickness of the crust in Central Spain is $\sim 31 \mathrm{~km}$ (Paulssen and Visser, 1993) the Hcrcyni itr crust furing the 
$M_{1}$ stage could have reached a thickness of $\sim 70-80 \mathrm{~km}$, which is more than the double the present thickness. This has important consequences when modelling the Hercynian tectonothermal evolution in the Central Iberian Zone, as the crustal thickening is a major factor controlling melting conditions during orogenesis (Patiño Douce and Johnston, 1991).

Eclogites described in other Hercynian Iberian sectors have been related to eo-Hercynian (430-365 Ma) subduction processes of continental wedges under oceanic crust as in the case of eclogites from the northwest branch (Martínez Catalán et al., 1996) or southwestern sectors (Leal et al, 1996). These eclogites are incorporated tectonically into major allochthonousparautoch thonous units and are closely related to mantle-derived peridotitic bodies, as is also typical in most of the European Hercynian eclogite-facies rocks (Carswell and Cuthbert, 1986; Bouchardon et al, 1989). In contrast, the eclogite-facies metabasites studied in the present work do not show any relationship with ultramafic mantle-derived rocks and lack a geochemical oceanic affinity, their chemical features being consistent with an intraplate continental affinity. The absence of tectonic contacts between the metabasites and host rock and the cofacial metamorphic evolution argues against any suggestion that the host rocks have never endured such high pressure conditions because they came into contact with the eclogites much later at some shallower depth. Thus is seems reasonable to state that no differences in metamorphic grade exist between the metabasites and the host rocks, the metabasites having suffered in situ eclogite-facies metamorphism and thus do not represent allochthonous units. Burial of the whole metamorphic sequence and subsequent eclogitization of the basic rocks might be related to intracontinental subduction thickening during the Hercynian collision.

\section{Acknowledgements}

Alfredo Fernán dez Larios and José González del Tánago are thanked for their assistance in microprobe analysis performed at CAI of Microscopía Electrónica from Complutense University. F. J. Fernández, P. J. O’Brien and an anonymous reviewer are thanked for their constructive comments. This work was supported financially by the project DGYCIT PB96-0661 of the Spanish Ministerio de Educación y Cultura.

\section{References}

Arenas, R., Fúster, J.M., González Lodeiro, F., Macaya, J., Martín-Parra, L.M., Martínez-Catalán, J.R. and Villaseca, C. (1991) Evolución metamórfica de la región de Segovia (Sierra de Guadarrama). Geogaceta, 4, 195-201.

Barbero, L. (1995) Granulite facies metamorphism in the Anatectic Complex of Toledo, Spain: late Hercynian tectonic evolution by crustal extension. J. Geol. Soc., 152, 365-82.

Berman, R.G. (1988) Internally-consistent thermodynamic data for minerals in the system $\mathrm{Na}_{2} \mathrm{O}$ $\mathrm{K}_{2} \mathrm{O}-\mathrm{CaO}-\mathrm{MgO}-\mathrm{FeO}-\mathrm{Fe}_{2} \mathrm{O}_{3}-\mathrm{SiO}_{2}-\mathrm{TiO}_{2}-\mathrm{H}_{2} \mathrm{O}-\mathrm{CO}_{2} . \mathrm{J}$. Petrol, 29, 445-522.

Berman, R.G. (1990) Mixing properties of Ca-Mg-FeMn garnets. Amer. Mineral, 75, 328-44.

Berman, R.G. (1991) Thermobarometry using multiequilibrium calculations: a new technique with petrological applications. Canad Mineral, 29, $833-55$.

Blundy, J.D. and Holland, T.J.B. (1990) Calcic amphibole equilibria and a new amphibole-plagioclase geothermometer. Contrib. Mineral Petrol, 104, 208-24.

Bouchardon, J.-L., Santallier, D., Briand, D., Ménot, R.-P. and Piboule, M. (1989) Eclogites in the French Paleozoic Orogen: geodynamic significance. Tectonophysics, 169, 317-32.

Carswell, D. A. and Cuthbert, S. J. (1986) Eclogite facies metamorphism in the lower continental crust. Pp. 193-209 in: The Nature of the Lower Continental Crust (J.B. Dawson, D. A. Carswell, J. Hall and K. H. Wedepohl, editors). Spec. Publ., 24. Geological Society, London.

Coleman, R.G., Lee, D.E., Beatty, L.B. and Brannock, W.W. (1965) Eclogites and eclogites: their differences and similarities. Geol. Soc. Amer. Bull, 76, 483-508.

Ellis, D.J. and Green, D.H. (1979) An experimental study of the effect of Ca upon garnet-clinopyroxene Fe-Mg exchange equilibria. Contrib. Mineral. Petrol, 71, 13-22.

England, P.C. and Thompson, A.B. (1984) Pressuretemperature-time paths of regional metamorphism I. Heat transfer during the evolution of regions of thickened continental crust. J. Petrol, 25, 894-928.

Escuder Viruete, J., Hernáiz, P.P., Valverde-Vaquero, P., Rodriguez Fernández, R . and Dunning, G. (1998) Variscan syncollisional extension in the Iberian Massif: structural, metamorphic and geochronological evidence from the Somosierra sector of the Sierra de Guadarrama (Central Iberian Zone, Spain). Tectonophysics, 290, 87-109.

Evensen, N. M., Hamilton, P.J. and O'Nions, R. K. (1978) Rare earth abundances in chondritic meteorites. 
Geochim. Cosmochim. Acta, 42, 1199-212.

Fuhrman, M.L. and Lindsley, D.H., (1988) Ternaryfeldspar modelling and thermometry. Amer. Mineral, , 73, 201-15.

Gasparik, T. and Lindsley, D. (1980) Phase equilibria at high pressure of pyroxenes containing monovalent and trivalent ions. Pp. 309-99 in: Pyroxenes (Ch.T. Prewitt, editor). Reviews in Mineralogy, 7. Mineralogical Society of America, Washington DC. Govindaraju, K. and Mevelle, G. (1987) Fully automated dissolution and separation methods for the inductively coupled plasma atomic emision spectrometry rock analysis - Application to the determination of rare-earth elements. J. Anal. Atom. Spectr., 2, $615-21$.

Graham, C.M. and Powell, R. (1984) A garnethornblende geothermometer: calibration, testing and application to the Pelona Schist, Southern California. J. Metam Geol., 2, 13-31.

Gutiérrez Marco, J.C., San José, M.A. and Pieren, A.P. (1990) Central Iberian Zone. Post-Cambrian Paleozoic stratigraphy. Pp. $160-71$ in: PreMesozoic Geology of Iberia (R.D. Dallmeyer and E. Martínez García, editors). Springer Verlag, Berlin.

Harley, S.L. (1984) An experimental study of the partitioning of $\mathrm{Fe}$ and $\mathrm{Mg}$ between garnet and orthopyroxene. Contrib. Mineral. Petrol., 86, $359-73$.

Hess, P.C. (1989) Origins of Igneous Rocks. Harvard University Press, Cambridge, MA.

Holdaway, M.J. (1971) Stability of andalusite and the aluminium silicate phase diagram. Amer. J. Sci, 27, 97- 132 .

Holland, T.J.B. (1980) The reaction albite $=$ jadeite + quartz determined experimentally in the range $600-1200^{\circ} \mathrm{C}$. Amer. Mineral., 65, 129-34.

Irvine, T.N. and Baragar, W.R.A. (1971) A guide to the chemical classification of the common volcanic rocks. Canad. J. Earth Sci, 8, 523-48.

Jamieson, R.A., Culshaw, N.G. and Corrigan, D. (1995) North-west propagation fo the Grenville orogen: Grenvillian structure and metamorphism near Key Harbour, Georgian Bay, Ontario, Canada J. Metam. Geol, 13, 185-207.

Kretz, R. (1983) Symbols for rock forming minerals. Amer. Mineral. , 68, 277-9.

Krogh, E.J. (1988) The garnet-clinopyroxene Fe-Mg geothermometer - a reinterpretation of existing experimental data. Contrib. Mineral Petrol, 99, $44-8$.

Laird, J. and Albee, A.L. (1981) Pressure-temperatures and time indicators in mafic schists: their application to reconstructing the polymetamorphic history of Vermont. Amer. J. Sci, 281, 127-75.

Leake, B.E. and 20 others (1997) Nomenclature of amphiboles: Report of the Subcommittee on
Amphiboles of the International Mineralogical Association Commission on New Minerals and Mineral Names. Mineral. Mag., 61, 295-321.

Leal, N., Pedro, J., Moita, P., Fonseca, P., Araújo, A and Munhá, J. (1996) Metamorfismo nos sectores meridionais da zona de Ossa-Morena: Actualizaçáo de conhecimentos. Estudios sobre a geologia da zona de Ossa-Morena (Maciço Ibérico) Livro Homenagem ao Prof. Francisco Gonçalves, Évora, 119-32.

Macaya, J., González-Lodeiro, F., Martínez Catalán, J.R. and Álvarez, F. (1991) Continuous deformation, ductile thrusting and backfolding of cover and basement in the Sierra de Guadarrama, Hercynian orogen of central Spain. Tectonophysics, 191, 291-309.

Martínez Catalán, J.R., Arenas, R., Díaz García, F., Rubio Pascual, F.J., Abati, J. and Marquínez, J. (1996) Variscan exhumation of a subducted Paleozoic continental margin: The basal units of the Órdenes Complex, Galicia, NW Spain. Tectonics, 15, $106-21$.

Martín Romera, C., Villaseca, C. and Barbero, L. (1999) Materiales anatécticos en el área de Sotosalbos (Segovia, Sierra de Guadarrama). Caracterización petroló gica, geoquímica e isotópica (Sr, Nd). Actas II Congreso Ibérico de Geoquímica, Lisboa, 329-32.

Medaris, G., Jelínek, E. and Mísar, Z. (1995) Czech eclogites: Terrane settings and implications for Variscan tectonic evolution of the Bohemian Massif. Eur. J. Mineral., 7, 7-28.

Messiga, B., Tribuzio, R. and Caucia, F. (1992) Amphibole evolution in Varican eclogite-amphibolite from the Savona crystalline massif (Western Ligurian Alps, Italy): Controls on the decompressional P-T-t path. Lithos, 27, 215-30.

Mullen, E.D. (1983) $\mathrm{MnO} / \mathrm{TiO}_{2} / \mathrm{P}_{2} \mathrm{O}_{5}$ : a minor element discriminant for basaltic rocks of oceanic environments and its implications for petrogenesis. Earth Planet. Sci. Lett., 62, 53-62.

O'Brien, P.J., Röhr, C., Okrusch, M. and Patzak, M. (1992) Eclogite facies relics and a multistage breakdown in metabasites of the KTB pilot hole, NE Bavaria: Implications for the Variscan tectonometamorphic evolution of the NW Bohemian Massif. Contrib. Mineral Petrol, 112, 261-78.

Patiño Douce, A.E. and Johnston, A.D. (1991) Phase equilibria and melt productivity in the pelitic system: implications for the origin of peraluminous granitoids and aluminous granulites. Contrib. Mineral. Petrol, 107, 202-18.

Paulssen, H. and Visser, J. (1993) The crustal structure in Iberia inferred from P-wave coda. Tectonophysics, 221, 111-23.

Pearce, J.A. and Norry, M.J. (1979) Petrogenetic implications of $\mathrm{Ti}, \mathrm{Zr}, \mathrm{Y}$ and $\mathrm{Nb}$ variations in 
volcanic rocks. Contrib. Mineral. Petrol., 69, 33-47.

Raheim, A. and Green, D.H. (1975) Experimental determination of the temperature and pressure dependence of the Fe-Mg partition coefficient of coexisting garnet and clinopyroxene. Contrib. Mineral Petrol, 48, 179-203.

Ridley, J. (1989) Vertical movement in orogenic belts and the timing of metamorphism relative to deformation. Pp. 103-15 in: Evolution of Metamorphic Belts (J.S.J. Daly, R.A. Cliff and B.W.D. Yardley, editors). Spec. Publ., 43. Geological Society, London.

Ringwood, A.E. (1975) Composition and Petrology of the Earth's Mantle. McGraw Hill, New York.

Robinson, P., Spear, F.S., Schumacher, J.C., Laird, J., Klein, C., Evans, B.W. and Doolan, B.L., (1982) Phase relations of metamorphic amphiboles: natural occurrence and theory. Pp. 1-27 in: Amphiboles and other Hydrous Pyriboles - Mineralogy (D. R. Veblen and P.H. Ribbe, editors). Reviews in Mineralogy, 9B. Mineralogical Society of America, Washington DC.

Rollinson, H. (1993) Using Geochemical Data: Evaluation, Presentation and Interpretation. Longman, Essex.

Ruppe1, C. and Hodges, K.V. (1994) Presssuretemperature-time paths from two-dimensional thermal models: prograde, retrograde, and inverted metamorphism. Tectonics, 13, 17-44.

San José, M.A. Pieren, A.P., García-Hidalgo, J.F., Herranz, P., Peláez, J.R. and Perejón, A. (1990) Central Iberian Zone. Anteordovician Stratigraphy. Pp. 147-59 in: Pre-Mesozoic Geology of Iberia (R.D. Dallmeyer and E. Martínez García, editors). Springer Verlag, Berlin.

Saunders, A.D. and Tarney, J. (1984) Geochemical characteristics of basaltic volcanism within back-arc basins. Pp. 59-76 in: Marginal Basin Geology (B.P. Kokelar and M.F. Howells, editors). Spec. Publ., 16. Geological Society, London.

Spear, F.S. (1991) On the interpretation of peak metamorphic temperatures in light of garnet diffusion during cooling. J. Metam. Geol., 9, 379-88.

Spear, F.S. (1993) Metamorphic Phase Equilibria and Pressure-Temperature-Time Paths. Monograph of the Mineralogical Society of America, Washington DC.

Sun, S. S. (1980) Lead isotopic study of young volcanic rocks from mid-ocean ridges, ocean islands and islands arcs. Phil. Trans. R. Soc., A297, 409-45.
Thompson, A.B., Schulmann, K. and Jezek, J. (1997) Extrusion tectonics and elevation of lower crustal metamorphic rocks in convergent orogens. Geology, 25, 491-4.

Valverde Vaquero, P. Hernáiz, P.P., Escuder, J. and Dunning, G.R. (1995) Comparison of the preCambrian and Paleozoic evolution of the Sierra de Guadarrama (Central Iberian Zone, Spain) and the Gondwana margin, NFLD Appalachians (GMNA) Terra Abstracts, 7, 278.

Viallete, Y., Casquet, C., Fuster, J.M., Ibarrola, E., Navidad, M., Peinado, M. and Villaseca, C. (1987) Geochronological study of orthogneisses from the Sierra de Guadarrama (Spanish Central System). Neues Jarhb. Mineral. Mh, H10, 465-79.

Villaseca, C. (1983) Evolución metamórfica del sector centro-septentrional de la Sierra de Guadarrama. $\mathrm{PhD}$ Thesis, Univ. Complutense de Madrid.

Villaseca, C. (1985) Microdioritas de afinidad toleítica en las bandas de cizalla de Segovia. Estudios Geológicos, 41, 11-5.

Villaseca, C. and Barbero, L. (1994) Estimación de las condiciones del metamorfismo hercínico de alta presión de la Sierra de Guadarrama. Geogaceta, 16, 27-30.

Villaseca, C. , Barbero, L. and Rogers, G. (1998) Crustal origin of Hercynian peraluminous granitic batholiths of Central Spain: petrological, geochemical and isotopic ( $\mathrm{Sr}, \mathrm{Nd}$ ) constraints. Lith $\bullet$, 43, 55-79.

Villaseca, C., Barbero, L., Huertas, M. J., Andonaegui, P. and Bellido, F. (1993) A cross-section through Hercynian granites of the Central Iberian Zone. Excursion Guide. C. S. I. C., Madrid.

Wildberg, H.D.H., Bischoff, L. and Baumann, A. (1989) $\mathrm{U}-\mathrm{Pb}$ ages of zircon from meta-igneous and metasedimentary rocks of the Sierra de Guadarrama: implications for the Central Iberian crustal evolution. Contrib. Mineral Petrol, 103, 253-62.

Willett, S.D., Beaumont, C. and Fullsack, P. (1993) Mechanical models for the tectonics of doubly vergent compressional orogens. Geology, 21, 371-4.

Winkler, H.G.F. (1976) Petrogenesis of Metamorphic Rocks. Springer, Berlin.

Wood, B.J. and Banno, S. (1973) Garnet-orthopyroxene and orthopyroxene-clinopyroxene relationships in simple and complex systems. Contrib. Mineral. Petrol., 42, 109-24. 
Selected equilibria used in TWQEE analysis (Berman, 1991). Numbers refer to those in the intersection diagrams in Fig. 9.

1. $\quad \mathrm{Jd}+\mathrm{Qz}=\mathrm{Ab}$

2. $\quad \mathrm{Py}+2 \mathrm{Grs}+3 \mathrm{Ab}=3 \mathrm{An}+3 \mathrm{Di}+3 \mathrm{Jd}$

3. $\quad 2 \mathrm{Grs}+\mathrm{Py}+3 \mathrm{Qz}=3 \mathrm{Di}+3 \mathrm{An}(\mathrm{Grt}-\mathrm{Cpx}-\mathrm{Plg}-\mathrm{Qz}$ barometer $)$

4. $\quad \mathrm{Alm}+2 \mathrm{Grs}+3 \mathrm{Qz}=3 \mathrm{Hd}+3 \mathrm{An}$

5. $3 \mathrm{Ab}+\mathrm{Alm}+2 \mathrm{Grs}=3 \mathrm{Jd}+3 \mathrm{Hd} 3 \mathrm{An}$

6. $\quad \mathrm{Alm}+3 \mathrm{Di}=\mathrm{Py}+3 \mathrm{Hd}(\mathrm{Grt}-\mathrm{Cpx}$ thermometer $)$

7. $4 \mathrm{Hd}+\mathrm{Py}+4 \mathrm{Rt}=3 \mathrm{Qz}+4 \mathrm{Im}+3 \mathrm{Di} \mathrm{An}$

8. $\quad 2 \mathrm{Rt}+\mathrm{Py}+2 \mathrm{Hd}+\mathrm{Grs}=2 \mathrm{An}+3 \mathrm{Di}+2 \mathrm{Ilm}$

9. $\quad \mathrm{Alm}+3 \mathrm{Hd}+6 \mathrm{Rt}=6 \mathrm{Qz}+6 \mathrm{Ilm}+\mathrm{Grs}$

10. $6 \mathrm{Rt}+\mathrm{Py}+6 \mathrm{Hd}=3 \mathrm{Di}+\mathrm{Grs}+6 \mathrm{Ilm}$

Abbreviations: Ab, albite; An, anortite; Alm, almandine; Di, diopside; Grs, grossular; Hd, hedenbergite; Ilm, ilmenite; Jd, jadeite; Py, pyrope; Qz, beta quartz; Rt, rutile. Other abbreviations follow Kretz (1983). 